\title{
Laccase Properties, Physiological Functions, and Evolution
}

\author{
Grzegorz Janusz ${ }^{1, *}$, Anna Pawlik ${ }^{1}$, Urszula Świderska-Burek ${ }^{2}$, Jolanta Polak ${ }^{1}$, \\ Justyna Sulej ${ }^{1}{ }^{\circledR}$, Anna Jarosz-Wilkołazka ${ }^{1}{ }^{1}$ and Andrzej Paszczyński ${ }^{3}$ \\ 1 Department of Biochemistry and Biotechnology, Maria Curie-Skłodowska University, Akademicka 19 Street, \\ 20-033 Lublin, Poland; anna.pawlik@poczta.umcs.lublin.pl (A.P.); jpolak@poczta.umcs.lublin.pl (J.P.); \\ justyna.sulej@poczta.umcs.lublin.pl (J.S.); anna.wilkolazka@poczta.umcs.lublin.pl (A.J.-W.) \\ 2 Department of Botany, Mycology and Ecology, Maria Curie-Skłodowska University, Akademicka 19 Street, \\ 20-033 Lublin, Poland; urszula.swiderska-burek@poczta.umcs.lublin.pl \\ 3 Professor Emeritus, School of Food Science, University of Idaho, Moscow, ID 83844, USA; \\ andrzej@uidaho.edu \\ * Correspondence: gjanusz@poczta.umcs.lublin.pl; Tel.: +48-81-537-5521
}

Received: 14 January 2020; Accepted: 30 January 2020; Published: 31 January 2020

\begin{abstract}
Discovered in 1883, laccase is one of the first enzymes ever described. Now, after almost 140 years of research, it seems that this copper-containing protein with a number of unique catalytic properties is widely distributed across all kingdoms of life. Laccase belongs to the superfamily of multicopper oxidases (MCOs) - a group of enzymes comprising many proteins with different substrate specificities and diverse biological functions. The presence of cupredoxin-like domains allows all MCOs to reduce oxygen to water without producing harmful byproducts. This review describes structural characteristics and plausible evolution of laccase in different taxonomic groups. The remarkable catalytic abilities and broad substrate specificity of laccases are described in relation to other copper-containing MCOs. Through an exhaustive analysis of laccase roles in different taxa, we find that this enzyme evolved to serve an important, common, and protective function in living systems.
\end{abstract}

Keywords: laccase; function; multicopper oxidase; polyphenol oxidase; lignin; melanin; evolution

\section{Introduction}

As the oxygen concentration in the biosphere increases due to the action of cyanobacteria, which started releasing photosynthetic oxygen to the Earth's atmosphere about 2.45 billion years ago, the widely available and water soluble FeII (ferrous ion) gradually oxidizes to FeIII (ferric ion) with practically no solubility in water and very limited availability to the living systems. In response to these changes, aerobic microbes developed highly sophisticated iron uptake (siderophores) and management systems [1], and the appearance of atmospheric oxygen created evolutionary pressure to find bioavailable metal(s) with iron-like high redox potentials. Therefore, the importance of copper (CuII/CuI) and manganese (MnIII/MnII) increased, especially in aerobic organisms as they embraced a similar but not identical role for iron (FeIII/FeII). Among many biological functions, copper interacts with a wide range of proteins to drive diverse structures and, hence, different biochemical reactions [1].

In general, copper-containing proteins, almost all extracellular, are widely distributed in nature, where they participate in oxygen transport and activation and electron(s) transfer in redox processes [2]. Multicopper oxidases belonging to this group are capable of oxidation of a wide range of substrates using oxygen as an electron acceptor. Multicopper oxidases (MCOs) reduce $\mathrm{O}_{2}$ to $\mathrm{H}_{2} \mathrm{O}$ without releasing harmful, partially reduced $\mathrm{O}_{2}$ molecules called reactive oxygen species (ROS). MCOs encompass 
laccases (EC 1.10.3.2) and a large family of copper oxidases, which include, among others, ascorbate oxidases (EC 1.10.3.3), ceruloplasmin (EC 1.16.3.1), bilirubin oxidase (EC 1.3.3.5), phenoxazinone synthase (EC 1.10.3.4), and metallo-oxidase Fet3p (EC 1.16.3.1). The amino acid sequences of all multicopper oxidases contain a small, $10-20 \mathrm{kDa}$, cupredoxin-like domain and possess relatively simple $3 \mathrm{D}$ structures, primarily composed of beta sheets and turns. They mainly serve as electron transfer proteins $[3,4]$. In recent years laccase structure was analyzed many times by means of crystallography. However, most of the described proteins are of a fungal or bacterial origin. Perhaps low amounts and methodically complicated purification protocols for plant and animal laccases make them difficult to be obtained as crystals. Nevertheless, it is proven that despite their wide taxonomic distribution and diversity of substrates, the molecular architecture of laccases is common for all multicopper oxidases [5,6].

The evolutionary tree of MCOs suggests a complex process in which different proteins, including taxonomically diverse laccases, most likely originated (Figure 1). In contrast to lignolytic peroxidases, which in the timeline of evolution appeared just before fungi gained the ability to decompose lignin [7], laccases are most likely one of the earliest metalloproteins, as they were present in organisms at the early evolutionary stages. Therefore, their lignolytic function is rather a result of substrate specialization and most likely the secondary function of these most frequently studied enzymes in the group of MCOs, which are widely distributed in fungi and bacteria and occur in higher plants and animals as well [8]. Based on the number of cupredoxin-like domains, MCOs are classified as two-domain (2dMCO), three-domain (3dMCO), and six-domain (6dMCO) enzymes [9]. Laccases usually contain three domains, like those described in fungi, plants, insects, and some bacteria, mostly composed of about 500 aa. In the past decade, small bacterial laccases (about 200 aa) were discovered and classified as 2dMCOs [3], and it was suggested that three-domain enzymes evolved from two-domain bacterial proteins (Figures 1 and 2). However, it is hard to elucidate the origin of short sequences (c.a. 170 aa) from vertebrates, which were annotated in recent years and some of them are biochemically categorized as laccases [10]. There is a chance that they may form a separate branch of MCO evolution, as their structures are rather close to prokaryotic laccases (Figures 1 and 2). Moreover, some fungal species, for example Pleurotus ostreatus, also produce laccases that are smaller than the typical $3 \mathrm{dMCO}$ and consist of only two domains [11]. It is highly probable that, during evolution, bacterial 2dMCO appeared before fungal 3dMCO (Figures 1 and 2). Despite the low amino acid sequence homology between fungal and bacterial laccases, their molecular architecture is similar, and the overall geometry of their active sites is highly conserved $[5,12,13]$. Three dimensional structure predictions for bacterial laccase suggest three sequentially arranged cupredoxin-like domains $[5,13]$ and copper ligands arranged in four conserved motifs (HXHG, HXH, HXXHXH, and HCHXXXHXXXXM/L/F) typical for the MCO family $[14,15]$. 


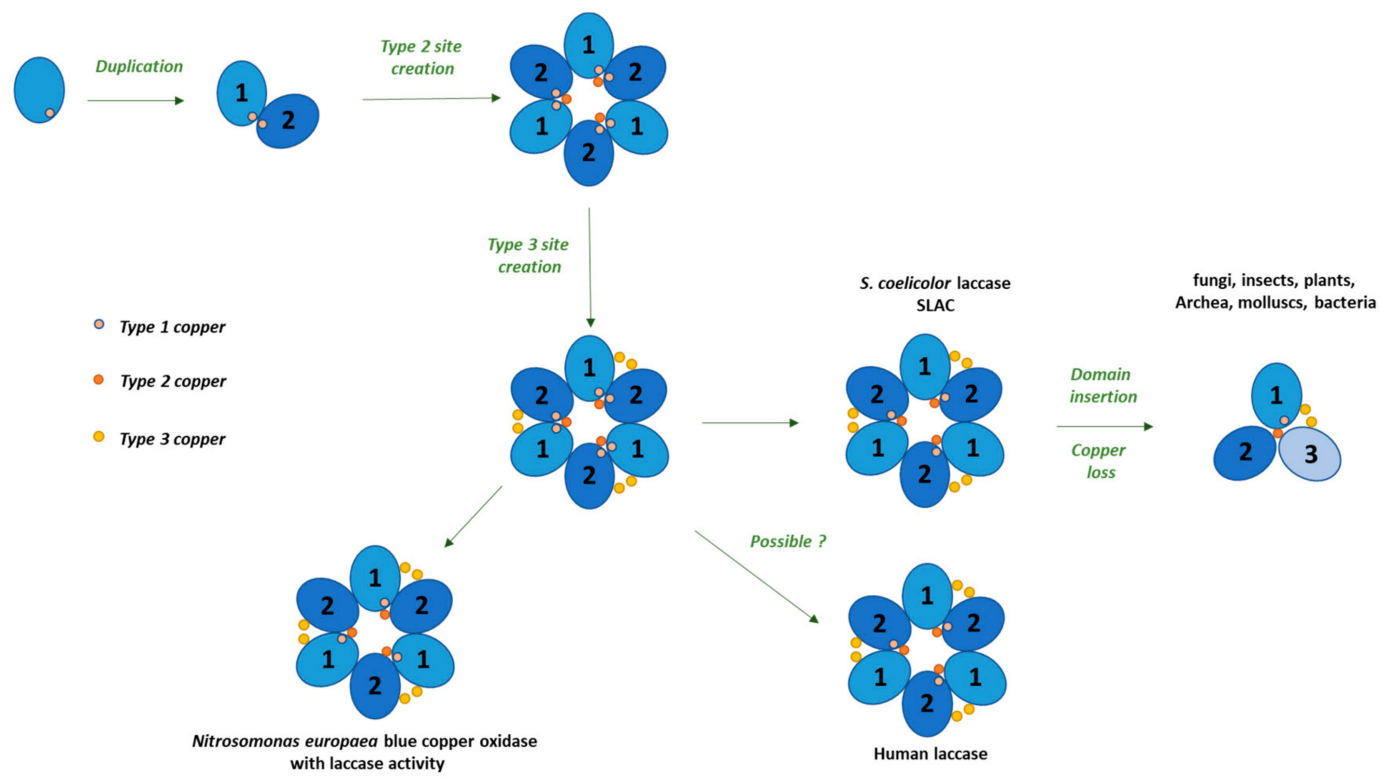

Figure 1. Schematic representation of the molecular evolution of laccases (based on Komori and Higuchi [11] and Nakamura and Go [16]). The oval shapes represent blue-copper-binding sites. The classes of protein domains are marked in pale and dark blue. Dots represent copper types.

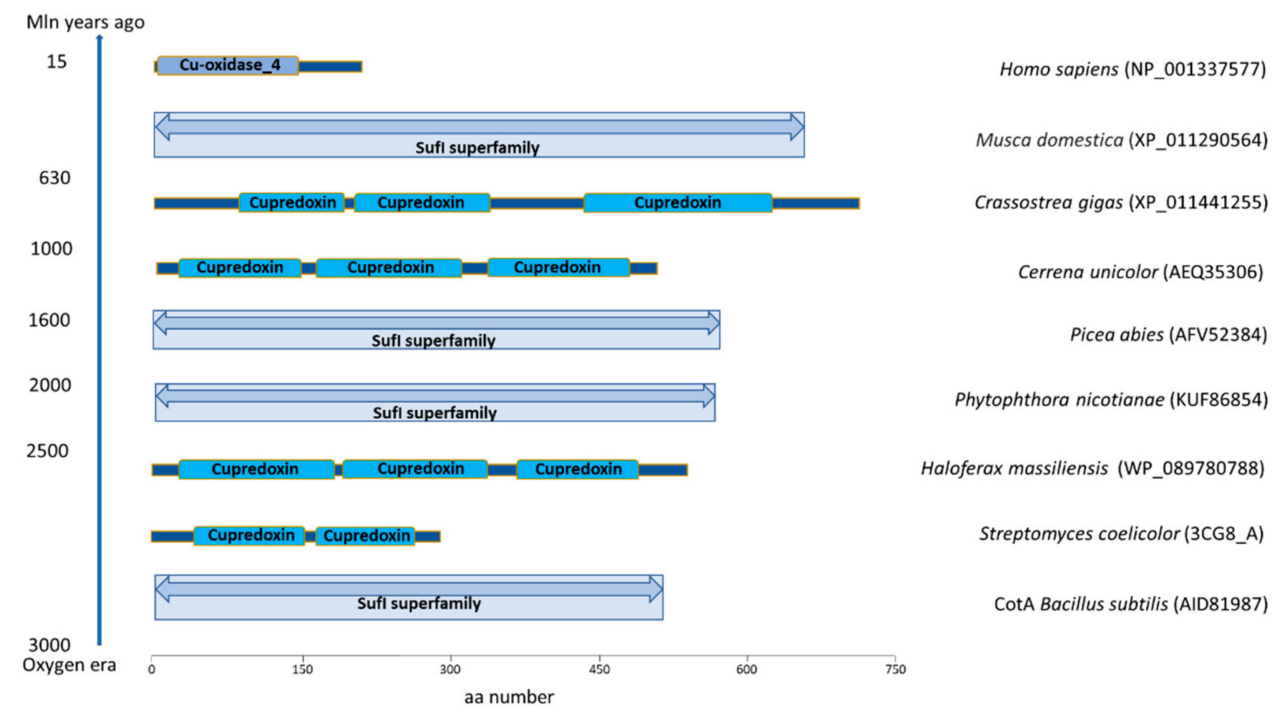

Figure 2. Conserved cupredoxin (cyan) laccase domains in different taxonomic groups. Cu-oxidase_4 is a multicopper polyphenol oxidoreductase laccase. Suf I represents a multicopper oxidase with three cupredoxin domains (includes cell division protein FtsP and spore coat protein CotA). The conserved domains were retrieved from the NCBI database. The appearance of organisms is shown in the timeline on the left in milliom (mln) years.

Therefore, questions arise whether small fungal laccases are a missing link between bacterial $2 \mathrm{dMCO}$ and fungal $3 \mathrm{dMCO}$ or whether fungi evolved $2 \mathrm{dMCO}$ independently by losing one domain. A similar process may have occurred in the animal kingdom. However, only fungi are known to produce $2 \mathrm{dMCO}$ and $3 \mathrm{dMCO}$ enzymes. Most laccases in a given species are coded by several genes, which is not an unusual phenomenon especially in eukaryotes. In most cases, this is caused by the need for large amounts of the gene product or catalytic subfunctionalization of a particular isozyme. A number of recent papers described the differential expression of laccases as a response to diverse environmental factors $[17,18]$, which most likely require synthesis of laccases with different substrate 
specificity and kinetic properties $[19,20]$. When considering numerous copies of laccase genes in many organisms and their diverse functions, subfunctionalization seems more convincing [21].

Interestingly, the human $L A C C 1$ gene shows no similarity to the other mammalian proteins, since it contains a C-terminal domain homologous to bacterial multicopper polyphenol oxidases (PO) and laccase [10]. Alignment of laccase sequences across the tree of life shows that they are grouped into main clades: two- and three-domain oxidases (Figure 3). The two-domain bacterial, mammalian, and coral laccases are clustered together in one clade. Not all laccases are two-domain; some species, including fungi, plants, and insects have three-domain laccases. The organisms clustered in these two separate groups comprise taxonomically different species (Figure 1). It should also be noted that two- and three-domain of these enzymes are present in animals and bacteria (Figure 2) and some Ascomycota laccases are more like those in plants and bacteria, which in turn are closer to insects than fungal enzymes. Moreover, Cryptococcus (animal and plant fungal pathogen) and Monoraphidium (green algae) laccases are grouped together separately from plant and fungal enzymes. It seems that this enzyme evolved from a single ancestral protein and later differentiated into structurally and functionally novel laccases across the tree of life; this process is expected to continue in the future. 


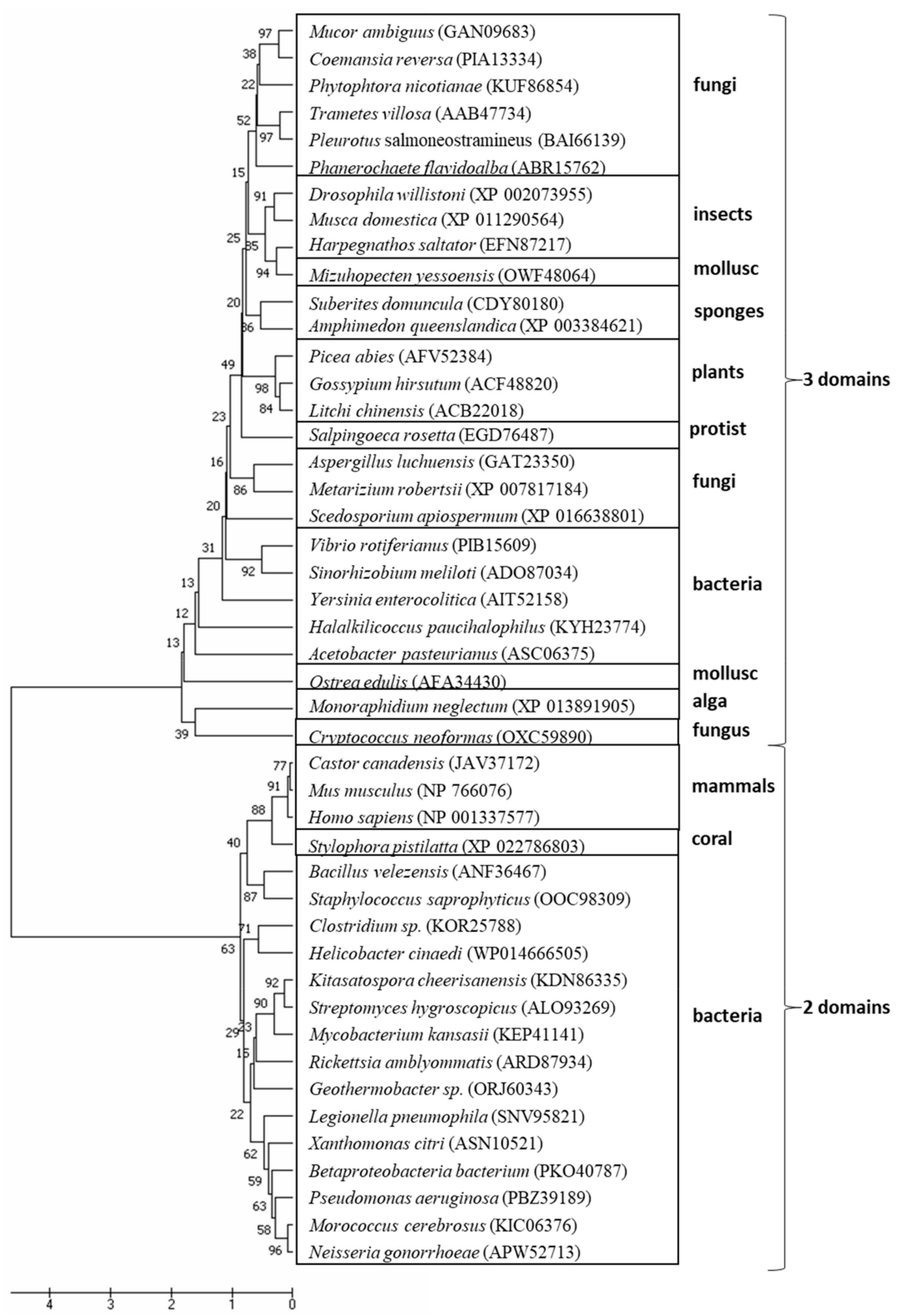

Figure 3. The evolutionary history of laccase was created using the UPGMA method [22]. The optimal tree with the sum of branch length $=38.42825656$ is shown. The percentage of replicate trees in which the associated taxa clustered together in the bootstrap test (1000 replicates) is shown next to the branches [23]. The tree is drawn to scale, with branch lengths in the same units as those of the evolutionary distances used to infer the phylogenetic tree. The evolutionary distances were computed using the Dayhoff matrix based method [24] and expressed in the units of the number of amino acid substitutions per site. The analysis involved 46 amino acid sequences. All positions containing gaps and missing data were eliminated. In total, there are 72 positions in the final dataset. The evolutionary analyses were conducted in MEGA7 [25].

\section{Laccase as a Versatile Biocatalyst}

The biologically important attributes of laccases include the broad substrate spectrum and the use of molecular oxygen as a final electron acceptor. The initial electron acceptor in laccase-catalyzed 
oxidation is copper $\mathrm{T} 1$ located in the cavity close to the enzyme surface [26]. The reduction of copper $\mathrm{T} 1$ is a rate-limiting step in the reactions catalyzed by laccase and the relatively low values of the $\mathrm{T} 1$ redox potential (from 420 to $790 \mathrm{mV}$ vs. normal hydrogen electrode (NHE)), which limit the laccase substrate array to molecules containing phenolic moieties [27]. Phenolic compounds are oxidized by laccase to phenoxyl radicals, which then engage in either coupling-based polymerization or radical rearrangement. However, depending on phenoxyl radical stability, redox reversibility featuring oxidation of a targeted substrate is observed. Radical-based coupling or redox recycling of phenolic substrates acting as mediators broadens the spectrum of laccase substrates [28].

Depending on the redox potential, laccases are divided into two groups: low- and high-redox-potential enzymes. Low-redox-potential enzymes occur in bacteria, plants, and insects, whereas high-redox-potential laccases are widely distributed in fungi [29]. Laccases catalyze both anabolic and catabolic reactions. Representative catabolic processes include degradation of lignin and humus by fungal laccases. Laccase-catalyzed anabolic reactions are involved in morphogenesis; for example, they catalyze polymeric pigment synthesis [30], cuticle sclerotization [31], polyflavonoid synthesis [32], lignification [33], and humidification of soil organic matter [34]. In anabolic processes, the redox potential of plant, bacterial, and insect laccases makes radical coupling reactions thermodynamically possible without additional chemicals [35]. Typical substrates for these reactions are low molecular weight phenolic compounds yielding several types of polymeric products such as pigments, lignins, polyflavonoids, and humus [32,36]. Purified laccases from plant tissues utilize monolignols and flavonoids as substrates for radical-based polymerization of lignin and polyflavonoid synthesis, as in the case of Eucalyptus lignin [37] or seed coat formation in Arabidopsis thaliana [38]. Oligomeric products derived from such reactions are randomly covalently coupled into cell wall components of plant fibers, like in Populus trichocarpa [39]. Similar radical-based coupling is described for laccases bounded to the insect cuticle matrix [40]. Cuticle sclerotization via laccase-mediated protein cross-linking processes was observed in the case of Manduca sexta and Tribolium castaneum [41]. Typical substrates in the cuticle sclerotization are catechol, $N$-acetyldopamine, and $N$ - $\beta$-alanyldopamine, which are transformed by laccase into quinones, followed by radical coupling of histidyl residues of cuticular proteins [42]. The cross-linking of these low molecular weight substrates to protein-based matrices is also essential for cuticle pigmentation, hardening, water-resistance, and protection against environmental stresses [31]. The main pigments synthesized by laccase are melanins formed from endogenous substrates such as dihydroxynaphthalene [43,44] and exogenous substrates such as homogentisic acid and dihydroxyphenylalanine [45]. Synthesis of the melanin pigment through laccase-catalyzed polymerization of the precursors mentioned above is described in C. neoformans [45] and Aspergillus fumigatus [44].

Catabolic processes performed by laccases require the generation of free radicals, which then oxidize target compounds such as lignin and humus. The first group of radicals is usually produced by fungal laccases from natural methoxyhydroquinones. Next, these radicals initiate Fenton reaction leading to production of different ROS [46,47]. The second group of radicals is generated by oxidation of natural low molecular weight redox mediators often derived from oxidized target substrates. For example, preferential oxidation of phenolic lignin units leads to the release of small phenolic residues with oxidized side chains [28]. In addition to the phenolic hydroxyl group, these compounds may contain additional functional residues, such as methoxyl, amine, ketone, aldehyde, or carboxyl. Such mediator-based oxidations occur principally in basidiomycetes, which are very efficient lignocellulose decomposers. Laccases alone do not depolymerize native lignin, but rather modify its surface [48]. However, the exact attack mechanisms and the enzymatic features of laccases in relation to lignin modification are presently unclear because of the lack of methods [29] to analyze these interactions. In the case of model phenolic compounds of lignin, laccase cleaves the bonds between $C_{1}$ and $C_{2}$ carbons, known as $C_{\alpha}-C_{\beta}$ cleavage, and between $C_{\alpha}$ and the aryl group, which is known as alkyl-aryl cleavage, without the use of a mediator [49]. It is suggested that laccase can cleave bonds of non-phenolic subunits of lignin only in the presence of a mediator [50,51]. Laccase redox 
mediators of natural origin are small molecular weight compounds which are lignin degradation products, plant phenolic secondary metabolites (e.g., vanillin, acetosyringone, and $p$-coumaric acid), or extracellular fungal metabolites, such as 4-hydroxybezylic alcohol, $p$-cinnamic acid, sinapic acid, syringaldehyde, or 3-hydroxyantharnillic acid [28,52]. These phenolic substances are oxidized by fungal laccase to phenoxyl radicals, which can oxidize non-phenolic residues of lignin, for example, through the hydrogen-abstraction mechanism [53]. Similar phenolic compounds are also observed within bacterial cultures capable of lignin degradation. For example, benzaldehyde with hydroxyl, methoxy, or trimethoxy substitutions is detected in Aneurinibacillus aneurinilyticus, Pseudonomas putida, Bacillus sp., Streptomyces sp., and Paucimobilis sp. cultures. The cinnamic acid with hydroxy and methoxy substitutions is reported in Bacillus sp. and P. putida cultures [54,55].

Some lignin-degradation-related phenolic compounds have mediation capacities when used in vitro but the presence of natural laccase mediators has not been proven during in vivo wood decay. When studying the sole action of laccase, it is difficult to exclude the possibility of interference from natural mediators, which are naturally present as phenolic compounds released from a lignin polymer [29].

\section{Polyphenol oxidase (PPO) Properties and Physiological Functions}

In the family of MCOs there are enzymes not only with laccase-like molecular structures but also those sharing similar catalytic functions. This group of enzymes, called polyphenol oxidases (PPOs), catalyzes the oxidation of phenols to quinones using molecular oxygen as a terminal electron acceptor [56]. PPOs are essential oxidases in biological systems, where they are involved in defense mechanisms, biosynthetic processes, polymerization, and detoxification of plant phenolic compounds [57]. In higher plants, the cross-linking of phenolic precursors is an important step in lignification [58]. PPOs are divided into three different groups: tyrosinases, catechol oxidases, and laccases, according to their substrate specificities and mechanisms of reactions $[59,60]$. Tyrosinases (E.C. 1.14.18.1; monophenol monooxygenase) catalyze the hydroxylation and oxidation of monophenols (including tyrosine, $p$-cresol, and $p$-coumaric acid) to $o$-diphenols and the oxidation of diphenols to the corresponding $o$-quinones [57]. Catechol oxidases (EC 1.10.3.1; 1,2-benzenediol: oxygen oxidoreductase also known as $o$-diphenol oxidase) solely catalyze the oxidation of $o$-diphenols to $o$-quinones (diphenolase activity). All PPO enzymes have an overlapping substrate spectrum and lack monophenol hydroxylating activity [61]. Cresolase and tyrosinases (EC 1.14.18.1) are the same enzymes differentiated according to their origin. Cresolases are ubiquitous PPOs in plants, whereas in animals, fungi, and bacteria, they are called tyrosinases [62]. Plant PPOs are predominantly located in the thylakoid membranes of chloroplasts, while the mammalian enzymes are usually present inside specialized melanocytes [63]. In some cases, polyphenol oxidases are secreted extracellularly [64].

PPOs oxidize phenolic or polyphenolic compounds, particularly flavonoids, which regulate all aspects of plant life [65]. These proteins are primarily responsible for enzymatic browning reactions and, therefore, play a leading role in plant defense against biotic and abiotic stresses [66]. During tissue injury, a melanin layer is built up as a protection against microbial pathogens [57]. Melanin polymers may contribute to the formation of protective barriers or be involved in the alkylation of proteins driven by PPOs, which in consequence may reduce the bioavailability of plant proteins for insects, or even the creation of a toxic environment for the invaders [67]. Oxidation of phenols to quinones activates a wound healing system and defense mechanisms in plants against herbivore insects and pathogens. Quinones bind covalently to leaf proteins and impede protein digestion in herbivores [68]. In addition to their role in the digestibility and palatability of plant tissues, melanin formation increases the cell wall resistance to insects and pathogens attack [69]. Later on, additional enzymes, such as phenoloxidase, quinone isomerase, and quinone methide isomerase, catalyze cross-linking reactions between quinonoid-reactive intermediates and cuticular components during sclerotization of insect cuticle in the wound healing process [70]. The same mechanism is observed when capsules are formed around parasites and parasitoids [71]. Quinones and other reactive intermediates (e.g., 
5,6-dihydroxyindole) are more toxic to herbivores than the original phenolic substrates and may kill microbial pathogens and parasitoids directly [72]. Many PPOs cooperate with peroxidases (PODs; EC 1.11.1.7) [73] and have diverse and overlapping physiological functions in plants, which include involvement in redox metabolism, responses to wound healing, defense against pathogens or insects, synthesis of lignin and suberin, and cross-linking of cell wall components [74,75].

PPOs are the key enzymes in melanogenesis and represent heterogeneous polyphenolic polymers widely distributed in all living systems. In mammals, melanin is responsible for skin, eye, and hair pigmentation and has a fundamental role in the protection against UV radiation [76]. Melanin is also found in reptiles, amphibians, and fish. In insects, melanin is involved in the sclerotization of the cuticle, defense mechanisms, and wound healing [71]. Melanogenesis is related to the innate immunity and cell hemostasis in insects [77]. Both tyrosinase and laccase contribute to the formation of melanin pigments in fungal and bacterial cells [78], although melanogenesis is restricted to certain developmental stages of the mycelium, fruiting body formation, and wound healing [77]. Fungal melanin is quite abundant and appears in the cell wall rather than in specialized subcellular organelles such as animal melanosomes. Usually, melanin precursors are secreted and then oxidized outside the cell and melanin granules are deposited on the cell wall surface, where they are likely cross-linked with polysaccharides $[77,79]$. In fungi, melanin contributes to cell wall pigmentation and resistance against hydrolytic enzymes [43]. The same process in bacterial cells and spores plays an important protective role against environmental stress factors such as harmful UV radiation and ROS, and most likely protects against toxic heavy metals [61]. It has been suggested that extracellular polyphenol oxidases in bacteria participate in the polymerization and detoxification of plant phenolic compounds in soil environments [80].

It is believed that the catabolic role of fungal laccases consists of the degradation of natural polymers such as lignin, most likely in synergy with other lignolytic enzymes [81]. These enzymes are classified into two groups: heme peroxidases (PODs) and lignin-degrading auxiliary enzymes (LDAs). Heme peroxidases comprise lignin peroxidase (EC 1.11.1.14), manganese peroxidase (EC 1.11.1.13), versatile peroxidase (EC 1.11.1.16), and dye-decolorizing peroxidase (EC 1.11.1.19). In turn, the accessory enzymes implicated in lignin degradation include aryl-alcohol oxidase (EC 1.1.3.7), glyoxal oxidase (EC 1.2.3.5), pyranose 2-oxidase (EC 1.1.3.10), glucose dehydrogenase (EC 1.1.99.10), cellobiose dehydrogenase (EC 1.1.99.18), and heme-thiolate haloperoxidases [7]. All these oxidases reduce oxygen to $\mathrm{H}_{2} \mathrm{O}_{2}$ required by peroxidases, effectively coupling polysaccharide and lignin anabolism. Cellobiose dehydrogenases (EC 1.1.99.18) enhance this link by reduction of phenoxy radicals, cations of transition metals (e.g., FeIII, CuII, and MnIII), or quinones using electrons from the oxidation of cellobiose to cellobionolactone, a process that also contributes to the availability of redox mediators for laccases [82].

\section{Bacterial Laccases}

The occurrence of MCOs with laccase activity has also been described in prokaryotes [83,84]. Due to differences in the catalytic mechanism, these enzymes are often referred as "polyphenol oxidases", "multicopper oxidases", or "laccase-like enzymes". However, they all catalyze oxidation of typical laccase substrates. The first prokaryotic protein with polyphenol oxidase activity (LMCO) was detected in non-motile Azospirillum lipoferum isolated from plant roots [85]. Isolated laccase occurs as a multimeric enzyme and its activity is correlated with production of a dark-brown pigment $[85,86]$.

The well-known producers of prokaryotic laccase include gram-positive and gram-negative soil and aquatic bacteria belonging to the phyla $\alpha$ - and $\gamma$-proteobacteria, Firmicutes, Cyanobacteria, Aquificae, and Deinococcus-Thermus, as well as members of Archaea (Table S1). The presence of laccase is reported in the following species: B. pumilus [87,88], B. subtilis [89], B. licheniformis [90], S. lavendulae [91], S. griseus [92], Escherichia coli [83], P. syringae [93], Thermus thermophilus [94], Sinorhizobium meliloti [95], Oscillatoria boryana [96], Haloferax volcanii [97], and Marinomonas mediterranea [98], including species living in extreme habitats $[94,99,100]$. In prokaryotes, the cellular localization of laccase varies considerably among species (Table S1). It is probably related to the physiological role of the 
enzyme and appears to be dependent on the growth phase and the presence of inducing substrates. Most of the natively expressed laccases are present intracellularly as in B. subtilis [101], S. meliloti [95], T. thermophilus [94], and M. mediterranea [98]. Bacterial cells must have a strategy to cope with the intracellular presence of laccase due to its possible toxic byproducts. Rearrangement of the electron transport system has been suggested as a way in which the laccase-positive cells adapt to endogenous reactive quinones generated by laccases [102]. However, the extracellular localization of laccase is demonstrated in some bacilli and filamentous actinomycetes [103,104]. Laccase-like genes are identified in important human pathogens such as E. coli, Bordetella pertusis, P. aeruginosa, Campylobacter jejuni, Yersinia pestis, and Mycobacterium leprae [83]. The production of melanin and laccase activity, most likely, contributes to the virulence of these species [105].

The best known bacterial laccase is the CotA protein, which is localized at the outer coat of the endospore of B. subtilis [89] and other bacillus species. The $65 \mathrm{kDa}$ CotA purified from an overproducing E. coli strain exhibits EPR spectra typical of the family of blue multicopper oxidases. The CotA structure has been elucidated with the use of comparative modeling. It contains all the features of a fungal laccase, including the surface-exposed copper center (T1) and two buried copper centers (T2 and T3) [101]. Analysis of the crystal structure revealed that the enzyme has a larger putative substrate-binding cavity than fungal or plant laccases [5]. Mutation of ligands in the T1 site impairs copper coordination, which alters the CotA biochemical properties drastically. The protein is highly thermostable with a half-life of about $2 \mathrm{~h}$ at $80^{\circ} \mathrm{C}$. The CotA recombinant laccase exhibits maximal activity for 2,2'-azino-bis(3-ethylbenzothiazoline-6-sulphonic acid (ABTS) and for syringaldazine (SGZ) oxidation at $\mathrm{pH} \leq 3.0$ and 7.0, respectively [101]. In contrast, SLAC protein has been identified in the genome of filamentous S. coelicolor [106]. This protein is a representative of the two-domain laccases with a substantially different protein architecture and appearing to be highly stable (Figure 1). The SLAC displays an unprecedentedly high $\mathrm{pH}$ optimum (9.4) for oxidation of 2,6-dimethoxyphenol (DMP); however, the recombinantly expressed enzyme exhibits paramagnetic properties typical for laccases [106]. Next to fungi, it is believed that actinomycetes are potent producers of laccases in nature [107], and their SLACs are thought to represent key evolutionary intermediates of the three-domain MCOs [16]. Still, their crystal structure resembles the structure of nitrite reductase or human ceruloplasmin more than that of a typical laccase [108,109].

The prokaryotic laccases described so far vary greatly in size from 32 to $180 \mathrm{kDa}$ and occur as monomers, trimers, and tetramers. Although there is undeniable evidence for prokaryotic protein glycosylation [110], glycosylation of bacterial MCOs has not been investigated extensively and there are only few reports related to the carbohydrate content of bacterial laccases $[97,107,111]$. Similarly, very little is known about the electrochemistry of prokaryotic MCOs (Table S1). Bacterial (and plant) laccases belong to low-redox potential enzymes, with a redox potential at the $\mathrm{T} 1$ site $\left(\mathrm{E}^{0^{\prime}}{ }_{\mathrm{T} 1}\right)$ below $460 \mathrm{mV}$ vs. NHE $[108,112,113]$. In comparison to fungal laccases, bacterial polyphenol oxidases are active at high $\mathrm{pH}$ values and much more stable at high temperatures. The high alkaline $\mathrm{pH}$ optimum (8.5 and 9 for ABTS and DMP, respectively) was shown for several Streptomyces laccases $[106,107,114]$, whereas the highest temperature optimum $\left(85^{\circ} \mathrm{C}\right)$ was reported for McoP isolated form Pyrobaculum aerophilum [112] and T. thermophilus laccase $\left(92^{\circ} \mathrm{C}\right)$ [94]. Interestingly, non-melanogenic alkali-tolerant $\gamma$-proteobacterium JB isolated from soil drained with industrial wastewater synthesizes laccase stably at $\mathrm{pH}$ from 3 to 10.6 [100]. S. ipomoea laccase retains $100 \%$ activity in $1 \mathrm{M} \mathrm{NaCl}$ at $\mathrm{pH} 8.0$ [115]. These extraordinary biochemical features underline prokaryotic laccases as a potential source of robust catalysts with possible biotechnological applications.

Bacterial MCOs with laccase activity are recognized as "moonlighting proteins" (i.e., multifunctional enzymes with multiple functions depending on their cellular localization) [116,117]. A probable mechanism of multifunctional enzyme switching has been hypothesized [116]. Although the possible functions of prokaryotic laccases were already discussed $[13,84,118,119]$, their biological role in vivo remains obscure and speculative. Most of the bacterial proteins identified so far are not often directly linked with lignin degradation [120-122]. Although never proven, the role and 
efficacy of bacterial laccases in lignin degradation is nowadays heavily studied [13]. Modification of the lignin polymer in order to allow access of other enzymes to cellulose and hemicellulose was suggested recently [122]. In general, laccase corresponding gene products are mainly involved in metal homeostasis/oxidation, sporulation, morphogenesis, and cell and spore pigmentation and are linked to resistance to different stresses. The Azospirillum laccase was reported to be involved in cell pigmentation [85], utilization of naturally occurring plant phenolic compounds resulting from lignin metabolism [123], and/or electron transport [102]. These capabilities could be related to the competitiveness of Azospirillum sp. in the rhizosphere and may play an essential role in colonization of plant roots, especially when the oxygen concentration changes in the soil environment [86]. The role of Streptomyces laccase in morphogenesis and pigmentation [124], lignocellulose degradation [125], bacteria-bacteria interactions, or antibiotic production [126] was speculated as well. In turn, most of the laccases identified in Bacillus are a part of the spore's outer coat that protects endospores from a diverse range of stresses. The $\cot A$ gene participates in the biosynthesis of a brown spore pigment, which is a melanin-like polymer responsible for protection against UV radiation. This view is supported by the direct observation of the protective effect of $\operatorname{Cot} A$ in a laccase-positive strain of B. subtilis, which appears more resistant than $\cot A$-deficient spores $[89,101]$. Moreover, brown-pigmented Bacillus sp. HR03 spores show remarkable resistance when exposed to hydrogen peroxide, UVA, and UVC. Therefore, the spore pigments in Bacillus are responsible for its resistance against harsh conditions, and laccase is an effective enzyme in the synthesis of these spore pigments [119,127]. The involvement of laccases in the cross-linking of spore coat proteins was postulated as well, which is somewhat analogous to the role of plant laccases in cell wall formation and is supported by the observation of tyrosine to di-tyrosine crosslinks in B. subtilis spores [12,128]. B. subtilis is capable of MnII oxidation, but its CotA is not involved in metal oxidation, unlike CumA, the spore coat protein of Pseudomonas sp. CumA is an MCO similar to laccase. It contributes to the oxidation of MnII, which may prolong the viability of the cell in the presence of ions of this metal [16,129]. Laccase-producing B. halodurans also show resistance against CuII toxicity [12]. Furthermore, laccase-like coding genes are also found in E. coli (PcoA and CueO, formerly YacK) and P. syringae (CopA). These pseudo-laccases structurally homologous to multicopper oxidases are important for bacterial copper resistance. A putative multicopper oxidase encoded by the yacK gene contains the predicted copper binding centers and displays phenol oxidase and ferroxidase activity. The enzyme moderates the sensitivity of E. coli to copper by exhibiting significant activity against siderophores utilized by E. coli for FeII uptake [130]. Moreover, E. coli CueO contains a Met and His-rich region, which partly covers the entrance to the T1 copper active site [131]. This region may provide additional Cu-binding sites and modify the active site structure upon CuII binding. Pseudomonas CopA shows limited but significant sequence homology with MCO proteins and is necessary for the expression of full copper resistance in these bacteria [132]. The role of laccase in cyanobacteria was investigated in relation to its bioremediation potential [133], suggesting its possible role in protecting the cell against harsh environmental conditions. However, only a few studies concerning cyanobacterial laccases have been reported [96,134].

\section{Plant Laccase-Species Range and Roles}

Laccase is isolated from gymnosperms and angiosperms, but in recent years, extracellular phenol oxidase from Tetracystis aeria (green algae) was confirmed as laccase according to the substrate specificity and properties of the purified enzyme [135]. Laccases have been detected in representatives of Anacardiaceae and other higher plants, including Pinus taeda, Acer pseudoplatanus, Nicotiana tabacum, P. trichocarpa, Liridendron tulipifera, Lolium perenne, A. thaliana, Zea mays, Oryza sativa, Saccharum officinarum, Brassica napus, and Brachypodium distachyon (Table S1) [136].

In 1883 Yoshida discovered that the first listed species in which laccase was detected was the Chinese lacquer tree Rhus vernicifera. Ten years later, Gabriel Bertrand isolated this enzyme from R. succedanea and other members of the Anacardiaceae family (e.g., Mangifera indica, Schinus molle, Pistacia palaestina, Pleiogynium timoriense) $[137,138]$. Laccase was located mostly in the resin ducts 
of these representatives. Production and secretion of laccase from cultures of A. pseudoplatanus was reported by Bligny and Douce [139] and the enzyme was later localized in xylem tissues of P. taeda [140], P. euramericana [141], and N. tabaccum [142]. The enzyme was also isolated from leaves of Aesculus parviflora [143].

The number of laccase isoforms in different plant species varies. For example, five laccases are expressed in the xylem of $P$. trichocarpa [141], eight laccases in the xylem tissues of $P$. taeda [32,140], and as many as 17 laccase genes in A. thaliana $[144,145]$. The molecular weight of plant laccases usually ranges between 60 and $130 \mathrm{kDa}$ with an average composition of 500 to 600 aa [136]. The optimum $\mathrm{pH}$ value varies mostly between $\mathrm{pH} 5-7$, and the isoelectric point (pI) ranges from 5 to 9.6 ; the enzymes are highly glycosylated $(22 \%-45 \%)[136,137,145]$. Plant laccases exhibit low redox potential of copper type I (T1) at about $430 \mathrm{mV}$ vs. NHE. A characteristic feature of plant laccases is the ability to oxidize the substrate without the help of mediators [146].

Plant laccases are reported to be involved in (1) lignification responsible for maintenance of the cell wall structure and mechanical rigidity; (2) plant responses to environmental stresses and defense mechanisms; (3) wound healing; (4) iron metabolism; and (5) polymerization of phenolic compounds (Figure 4) [136,137,145,147-149]. The ability to oxidize lignin precursors suggests involvement of plant laccases in the lignification of the plant cell wall [32,140,141,150,151]. Laccase enzymes are secreted to the apoplast, where they catalyze the synthesis of lignin and regeneration of damaged plant tissues.

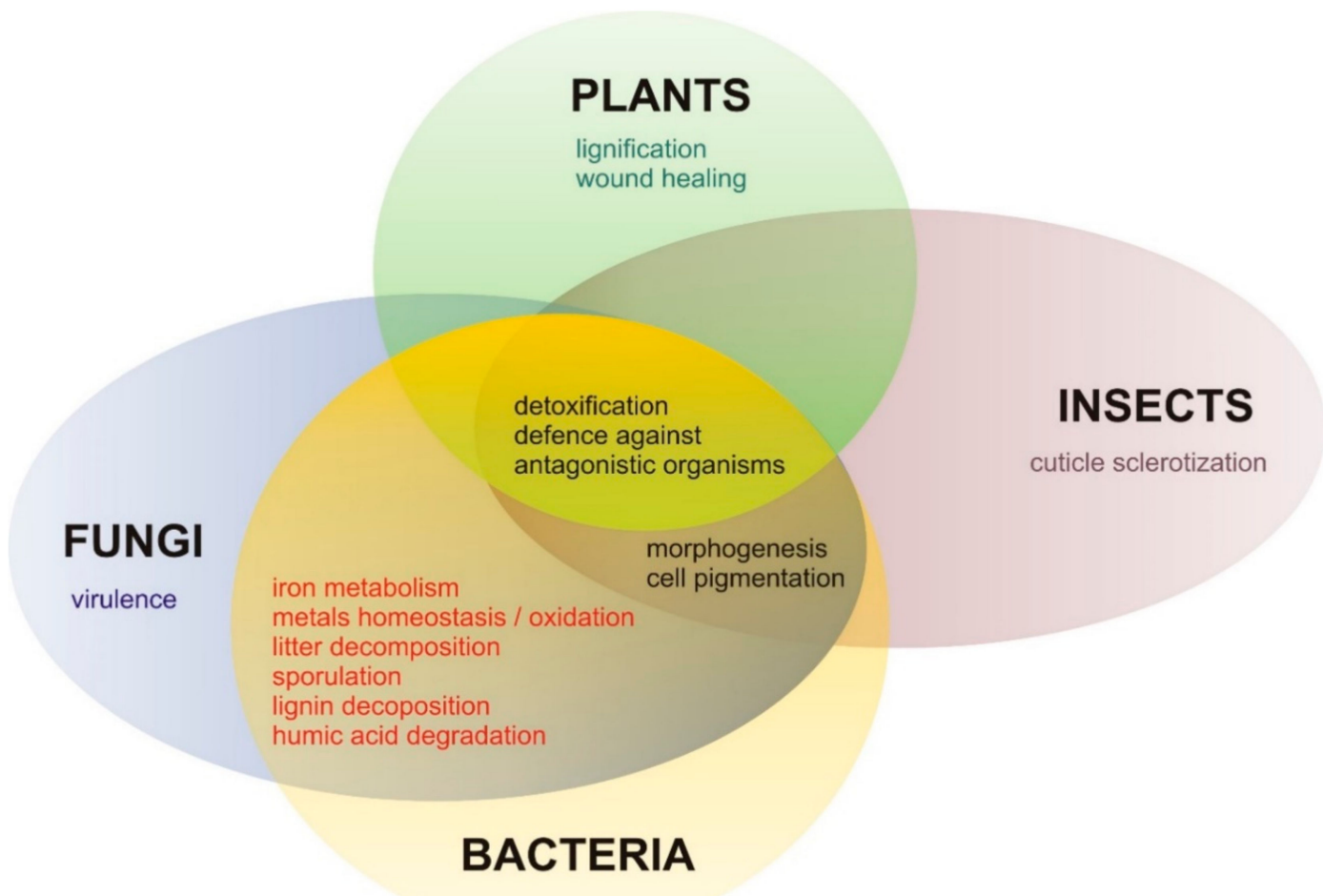

Figure 4. Comparison of laccase biological functions in different organisms. The protective role is common for all taxonomic groups and, most likely, it is the primary role of laccases in all living organisms. Other functions are most probably the result of specialization of this enzyme, which narrows its substrate spectrum.

A. thaliana laccase is responsible for stem lignification while in Populus sp. it is present in other organs and tissues, such as the seed coat [145]. The presence of the enzyme in the resin ducts of Anacardiaceae indicates a defense function against herbivores, predators, and bacterial and fungal invasion [147]. It was found that during seed storage and germination, the TT10 gene related to the formation of antimicrobial quinones participates in the creation of a barrier against pathogens 
in Arabidopsis [62]. In A. thaliana, laccases expressed in the seed-specific group are involved in the polymerization of seed coat flavonoids and the production of insoluble brown polymers with a putative protective function [144,145].

The main role of green algal laccases includes detoxification of phenolic compounds present in both terrestrial and aquatic environments, involvement in the synthesis of cell wall-associated polymers and UV-absorbing compounds, and metabolism of lignocellulosic substrates resulting in acquisition of nutrients. In algae, laccases may greatly contribute to the biotransformation of natural and xenobiotic aromatic compounds, including known environmental pollutants [135].

\section{Fungal Laccases-Occurrence, Roles, Similarities, and Differences}

Most of the information about fungal laccases originates from species belonging mainly to Basidiomycota and Ascomycota (Table S1). Fungal laccases are involved in the decomposition of lignocellulose polymers, defense/protection, virulence, pathogenesis, pigmentation, and sporulation processes (Figure 4). The main function of fungal laccase is biodegradation of lignocellulose and thus contribution to the carbon cycle in the biosphere $[7,138,152,153]$. The lignin polymer is highly resistant towards chemical and biological degradation, making wood decay a slow and biologically difficult process. Fungal laccases, especially those from white-rot species, are reported to exhibit high redox potential, close to $800 \mathrm{mV}$ vs. NHE, facilitating abstraction of electrons from substrates, which may also act as redox mediators during the attack of laccase on lignin. As reported by Munk, Sitarz, Kalyani, Mikkelsen, and Meyer [29], fungal laccase can cleave bonds without the use of mediators in phenolic lignin model compounds. In the case of non-phenolic subunits of lignin, cleavage of covalent bonds by laccase is possible only by using mediators [29]. Moreover, laccase gene expression can be induced by natural plant derivatives (e.g., gallic or ferulic acids) that may occur in fungal cells during fungal infection [154].

Litter decomposition is the key step in nutrient recyclin (i.e., a highly complex process mediated by various fungal taxa with rapid succession of saprotrophic species) [155]. Among different organisms equipped with extracellular enzymes involved in this process, Ascomycota and Basidiomycota are dominant but also other fungi, especially Zygomycota and Glomeromycota, are observed [155-158]. Laccase genes were detected in litter-degrading fungi and the number of basidiomycete laccase genes was 5-10 times greater in organisms occurring in high-lignin forest floor than in a low-lignin environment $[29,157]$. Interestingly, aquatic fungal species were denied the ability to decompose lignin for many years. However, taxa belonging mainly to Ascomycota, Chytridiomycota, and Oomycota are major decomposers of litter and able to produce laccase as well [156]. Two laccase encoding gene fragments were found by Sole et al. [159] in pure cultures of Clavariopsis aquatica and it was suggested that laccase is a cell-associated enzyme [159,160]. Other fungi belonging to aquatic hyphomycetes [161] and aquatic Ascomycota, such as Phoma sp. and Coniothyrium [162], possess laccase activity as well.

In nature, the other important deposit of carbon is humic substances (HS), which are dark-colored organic materials formed during chemical and biological transformation of mainly plant residues but also animal and human wastes $[163,164]$. The main building blocks of HS are phenols, quinones, carbohydrates, as well as higher molecular mass compounds such as lignins, polysaccharides, melanins, and cutins. Microorganisms, especially fungi producing oxidizing enzymes, play the key role in HS formation, degradation, transformation, and finally mineralization [165]. Chefetz, Chen and Hadar [34] confirmed that laccase from Chaetomium thermophilum plays a significant role in the humification process by forming water-soluble polymers containing hydrophobic acids. In contrast, degradation and transformation of HS are catalyzed mainly by Basidiomycota enzymes. The pathway of transformation (humification vs. HS degradation) depends on substrate availability and such reaction conditions as the $\mathrm{pH}$ value, humidity, and presence of co-substrates [165]. Since $\mathrm{pH}$ plays a critical role, the engagement of different laccase isoenzymes may be important for improvement of the efficiency of degradation/transformation of HS [165]. Feng et al. [166] suggested a correlation between 
the abundance and diversity of fungal and bacterial laccase activity in arable subtropical soil, and the laccase activity was mainly of bacterial origin.

Laccase secretion is considered as one of the basic fungal responses to the presence of antagonistic conditions: other microorganisms, xenobiotics, metals, toxins, and biologically active compounds. Fungal laccases oxidize not only phenolic compounds but also non-phenolic substrates such as aromatic amines, polycyclic aromatic hydrocarbons, synthetic dyes, antibiotics, and other non-obvious laccase substrates [35,167]. In this way, laccase is a very useful enzymatic "tool" for elimination of natural or synthetic toxins occurring in the environment and is therefore involved in fungal active defense.

The induction of laccase secretion by cultures of Agaricus bisporus, P. ostreatus, and Lentinula edodes as a response to the presence of Trichoderma sp. was demonstrated [168-170]. As described by Sjaarda et al. [171], the expression of A. bisporus laccase genes is also induced by the presence of a toxic extract of T. aggressivum in the medium, and the resistance is correlated with the laccase activity. Interestingly, $T$. viride laccase secretion enhances in the presence of Bacillus sp. and A. ochraceus cells. Lakshmanan and Sadasivan [172] reported recently that inhibition of $T$. viride laccase causes the inability of this fungus to compete with antagonistic microorganisms.

Botrytis cinerea BcLCC2 laccase is an example of the involvement of this enzyme in defense against antibiotics such as 2,4-diacetylphloroglucinol (2,4-DAPG). The degradation of 2,4-DAPG occurs only in the presence of tannic acid used as the redox mediator [173]. Interestingly, laccase plays a role as a catalyst during cinnabarinic acid synthesis in Pycnoporus cinnabarinus. Cinnabarinic acid is an antibacterial compound, which may well protect this fungus from microbial predations $[174,175]$. Laccases are key enzymes in melanin metabolism. Many melanin pigments are antimicrobial and act as a virulence factor contributing also to the fungal species survival. They are found in bacterial endospores, fungal spores/conidia, or within cell walls and can secrete into the environment [176]. A correlation between $C$. neoformans melanisation and the ability to infect humans has been studied. This yeast-like fungus causes childhood infection and cryptococcal pneumonia-like disease and meningo-encephalitis (cryptococcosis) [177]. The expression of a single CNLAC1 gene in a C. neoformans culture is induced by glucose starvation, acidification, and lowered temperature [178-181]. The pigment produced by $C$. neoformans in the presence of an exogenous substrate is characterized as a melanin-like compound, and laccase is identified as a main diphenol oxidase involved in its formation [182-184]. Notably, the melanin-like precursors include catecholamine, dopamine, adrenaline, and noradrenaline present in the mammalian central nervous system, which may explain the neurotropism of $C$. neoformans [180,185]. Laccase of C. neoformans also promotes virulence by reducing FeIII to FeII, thus inhibiting the oxidative burst in macrophages and, consequently, the enzyme has a negative effect on innate immunity [186]. C. neoformans laccase is tightly associated with the cell wall [187] and can therefore easily is part of the response to toxic hydroxyl radicals produced by macrophages [186].

Infection of AIDS patients caused by Talaromyces marneffei suggests a potential role of laccase in the virulence of this opportunistic pathogen [188-190]. A possible mechanism is associated with the production of a red soluble pigment by both yeast and mold forms of T. marneffei. To understand the role of laccase in virulence of T. marneffei, single, double, triple, and quadruple deletions of genes encoding lacA, lacB, lacC, and pbrB laccases were obtained. Only conidia from the quadruple mutant showed increased sensitivity to the antifungal agents and vulnerability to phagocytosis and killing by monocyte cell line THP-1 $[188,190]$. These results suggest that the laccase of T. marneffei promotes resistance of this pathogen to host immune defenses [188]. The pigment or other laccase products reduce immune recognition, potentially interfering with signaling pathways in monocytes [190]. Laccase genes are also found in the genome of Fonsecaea sp., which belongs to black yeast-like fungi with clinical importance [191].

Colletotrichum gloeosporioides is the main causal agent of anthracnose of Mangifera indica fruits [192]. Lac1 mutants with a disrupted lac gene (LAC1) are less pigmented, rarely produce conidia, and have reduced aerial mycelial mass and radial growth rates. The lac1 mutants are also less virulent during virulence tests on both wounded and non-wounded mango leaves and fruits. As reported by Kuo et 
al. [193], laccases in Heterobasidion annosum may act as a virulence factor during interactions with $P$. sylvestris seedlings [193]. Summarizing, inhibition of melanin synthesis in the fungal pathogen could be a viable approach to control diseases caused by fungi in plants and animals and may help to protect lumber against fungal decay.

Two phylogenetically closely related fungi, T. atroviride and T. harzianum, produce yellowish and green spores, respectively, but laccase activity is detected only during formation of darker green spores. The laccase activity is associated with the spore surface and is linked to the melanin-like polymer present in the cell wall or in the periplasm of the spore capsules. This research indicates that the spore-associated laccases are involved in the formation of the melanin pigment, which protects spores against temperature, UV light, and hydrolytic enzymes [194].

\section{Occurrence and Function of Laccase in Animals}

In the animal kingdom, insect laccases are most intensively studied. The enzyme is detected in members of the following insect genera: Anophales, Apis, Bombyx, Calliphora, Diploptera, Drosophila, Lucilia, Menduca, Monochamus, Musca, Oryctes, Papilio, Phormia, Rhodnius, Sarcophaga, Schistocerca, and Tenebrio [41,195-201]. They mostly belong to the orders Hymenoptera, Diptera, Lepidoptera, and Coleoptera (Table S1).

Several isoforms have also been described in mollusks [202], and the presence of the enzyme was confirmed in the lowest metazoan taxon (i.e., sponges). The laccase of Suberites domuncula showed high sequence similarity with the insect laccases, including Bombus impatiens, Apis mellifera, and Acromyrmex echinatior, and with nematode enzymes from Caenorhabditis remanei, Ancylostoma ceylanicum, and Haemonchus contortus [202]. Recently, genetic variation in the gene coding for human laccase has been associated with the risk of Crohn's disease, leprosy, ulcerative colitis, and juvenile idiopathic arthritis [10]. In many mammalian species, putative sequences coding for this enzyme are identified (Table S1). Interestingly, laccase s found in epithelial cells of human and termite intestines [203,204]. In insect intestines, laccase plays a most likely protective role against toxic lignin derivatives resulting from a plant-based diet. Moreover, it is localized intracellularly $[195,196]$ and the molecular mass identified in several insect species (including M. sexta) varies from 70 to $100 \mathrm{kDa}$ [205]. The values of $\mathrm{pH}$ and $\mathrm{pI}$ vary between 5-6.5 and 5.1-6.3, respectively [49,198]. In comparison to plant and fungal laccases, insect enzymes have an extended amino-terminal region [198].

Sponges most likely utilize laccase as an antimicrobial agent [202] and for detoxification of xenobiotics and elimination of lignin-derived products from their filtered food. The best-described function of laccase in insects is its involvement in cuticle sclerotization in the epidermis of larval, pupal, and adult developmental stages of Drosophila virilis $[27,136,198,201,206]$. The sclerotization involves oxidative incorporation of acyldopamines: $N$-acetyldopamine (NADA, IV) and $N$ - $\beta$-alanyldopamine into the cuticular matrix before ecdysis (pre-ecdysial sclerotization) or soon after ecdysis (post-ecdysial sclerotization). In some members of the order Diptera, sclerotization of soft larval cuticle occurs during puparium formation $[207,208]$. Laccase gene expression and activity in the D. virilis, L. cuprina, and B. mori life cycle is low in the intermolt period and increases drastically later during puparium formation to decrease again thereafter [198,207]. Two main forms of laccase are found in insects: laccase- 1 and laccase-2. Laccase-2 is involved in cuticle tanning (e.g., in larval, pupal, and adult stages) of T. castaneum and M. sexta [41,198], while laccase-1 is expressed in the salivary glands, midgut, Malpighian tubules, fat body, and epidermis of $M$. sexta. Laccase- 1 also oxidizes toxic compounds ingested by insects, thus playing a protective role in the insect gut $[198,207,209]$. Another well-known biological function of laccase in insects is production of melanin in the midgut as a primeval immune response against invasion of parasites [147], as described in D. melanogaster [210]. Studies of the laccase-2 gene from $M$. sexta and B. mori showed high expression in the epidermis prior to ecdysis. However, the cuticle of newly molted pupae does not have laccase activity, and the activity becomes detectable only several hours after ecdysis. These data suggest that cuticle laccase is synthesized as an inactive precursor, which is activated after the ecdysis stage $[198,211]$. In Monochamus alternatus, laccase-2 plays a role 
in pupal pigmentation and sclerotization of adult cuticle [199]. These two processes (sclerotization and pigmentation), known as cuticle tanning, involve the formation of covalent cross-links between polypeptides via oxidative and nucleophilic reactions of catechols and side-chain groups of amino acids. The protein conjugation causes hardening and darkening of the exoskeleton, cuticle, egg capsule, chorion, ootheca, and silk cocoon of insects [41]. Hattori et al. [212] identified a laccase in the salivary glands of Nephotettix cincticeps, which secretes a watery saliva involved in the detoxification of potentially toxic monolignols during the insect's feeding [209]. A role of $M$. sexta laccase in the oxidation of toxic compounds in food and/or in iron metabolism has been proposed [151,198].

\section{Conclusions}

Scientific data suggest that laccase evolved as one of the first copper-containing enzymes in the oxygen era of the biosphere. With numerous organic and inorganic substrates, this enzyme is engaged in a variety of catalytic functions, which is generally described as protective against adverse environmental factors, including competitive or parasitic organisms and toxic compounds. The protective role of laccase has become so important that its' genes have spread in numerous taxonomic groups, excluding only anaerobic organisms, in the course of evolution. Moreover, the low substrate specificity of laccases facilitates the use of this protein as an important virulence factor that protects infectious cells against host immune defense. Recent reports on laccase in humans may lead to the discovery of novel functions of this enzyme, which may be examined for the first time as part of the most complicated machinery of the human body.

Since numerous copies of laccase genes are present in many organisms, their further duplication in genomes is expected. This phenomenon may result in subfunctionalization of newly evolved laccases, which in consequence allow organisms to explore new food sources and protect themselves from future adverse conditions. Changes in the laccase structure, for example, duplication or deletion of cupredoxin-like domains, are possible, as it already happened in different taxa in the past.

Supplementary Materials: Supplementary materials can be found at http://www.mdpi.com/1422-0067/21/3/966/s1, Table S1. Comparison of selected laccases from different taxa.

Author Contributions: Conceptualization: all; methodology: all; software: A.P. (Anna Pawlik) and G.J.; formal analysis: A.P. (Anna Pawlik) and G.J.; writing—original draft: all; writing—review and editing: G.J., A.P. (Anna Pawlik), A.P. (Andrzej Paszczyński), and A.J.-W.; visualization: G.J., U.Ś.-B., and A.P. (Anna Pawlik); supervision: G.J. and A.P. (Andrzej Paszczyński); funding acquisition: G.J., A.P. (Anna Pawlik), J.S., and A.J.-W. All authors have read and agreed to the published version of the manuscript.

Funding: This work was financially supported by the National Science Centre (Poland) based on the decision number DEC-2014/15/B/NZ9/01990, DEC-2013/09/B/NZ9/01829, 2017/01/X/NZ9/00819, 2016/21/D/NZ9/02460, 2014/13/B/NZ9/02106 and the research program BS/UMCS.

Conflicts of Interest: The authors declare no conflicts of interest. The funders had no role in the design of the study; in the collection, analyses, or interpretation of data; in the writing of the manuscript, or in the decision to publish the results.

\section{Abbreviations}

2,4-DAPG 2,4-diacetylphloroglucinol

ABTS 2,2'-azino-bis(3-ethylbenzothiazoline-6-sulphonic acid)

DMP (2,6-dimethoxyphenol)

LDA lignin-degrading auxiliary enzymes

LMCO laccase-like multicopper oxidase

MCO multicopper oxidase

NHE normal hydrogen electrode

POD ligninolytic class II peroxidases

PPO polyphenol oxidase

ROS reactive oxygen species

SGZ syringaldazine 


\section{References}

1. Andrews, S.C.; Robinson, A.K.; Rodriguez-Quinones, F. Bacterial iron homeostasis. FEMS Microbiol. Rev. 2003, 27, 215-237. [CrossRef]

2. Crichton, R.R.; Pierre, J.L. Old iron, young copper: From Mars to Venus. Biometals 2001, 14, 99-112. [CrossRef]

3. Komori, H.; Higuchi, Y. Structural insights into the O-2 reduction mechanism of multicopper oxidase. J. Biochem. 2015, 158, 293-298. [CrossRef] [PubMed]

4. Choi, M.; Davidson, V.L. Cupredoxins-A study of how proteins may evolve to use metals for bioenergetic processes. Metallomics 2011, 3, 140-151. [CrossRef] [PubMed]

5. Dwivedi, U.N.; Singh, P.; Pandey, V.P.; Kumar, A. Structure-function relationship among bacterial, fungal and plant laccases. J. Mol. Catal. B Enzym. 2011, 68, 117-128. [CrossRef]

6. Kallio, J.P.; Gasparetti, C.; Andberg, M.; Boer, H.; Koivula, A.; Kruus, K.; Rouvinen, J.; Hakulinen, N. Crystal structure of an ascomycete fungal laccase from Thielavia arenaria - common structural features of asco-laccases. FEBS J. 2011, 278, 2283-2295. [CrossRef] [PubMed]

7. Janusz, G.; Pawlik, A.; Sulej, J.; Swiderska-Burek, U.; Jarosz-Wilkolazka, A.; Paszczynski, A. Lignin degradation: Microorganisms, enzymes involved, genomes analysis and evolution. FEMS Microbiol. Rev. 2017, 41, 941-962. [CrossRef] [PubMed]

8. Sakurai, T.; Kataoka, K. Basic and applied features of multicopper oxidases, CueO, bilirubin oxidase, and laccase. Chem. Rec. 2007, 7, 220-229. [CrossRef]

9. Hakulinen, N.; Rouvinen, J. Three-dimensional structures of laccases. Cell Mol. Life Sci. 2015, 72, 857-868. [CrossRef]

10. Assadi, G.; Vesterlund, L.; Bonfiglio, F.; Mazzurana, L.; Cordeddu, L.; Schepis, D.; Mjosberg, J.; Ruhrmann, S.; Fabbri, A.; Vukojevic, V.; et al. Functional analyses of the crohn's disease risk gene LACC1. PLoS ONE 2016, 11, e0168276. [CrossRef]

11. Komori, H.; Higuchi, Y. Structure and molecular evolution of multicopper blue proteins. Biomol. Concepts 2010, 1, 31-40. [CrossRef] [PubMed]

12. Ruijssenaars, H.J.; Hartmans, S. A cloned Bacillus halodurans multicopper oxidase exhibiting alkaline laccase activity. Appl. Microbiol. Biotechnol. 2004, 65, 177-182. [CrossRef] [PubMed]

13. Chandra, R.; Chowdhary, P. Properties of bacterial laccases and their application in bioremediation of industrial wastes. Environ. Sci. 2015, 17, 326-342. [CrossRef] [PubMed]

14. Reiss, R.; Ihssen, J.; Richter, M.; Eichhorn, E.; Schilling, B.; Thöny-Meyer, L. Laccase versus laccase-like multi-copper oxidase: A comparative study of similar enzymes with diverse substrate spectra. PLoS ONE 2013, 8, e65633. [CrossRef]

15. Ihssen, J.; Reiss, R.; Luchsinger, R.; Thony-Meyer, L.; Richter, M. Biochemical properties and yields of diverse bacterial laccase-like multicopper oxidases expressed in Escherichia coli. Sci. Rep. 2015, 5, 10465. [CrossRef]

16. Nakamura, K.; Go, N. Function and molecular evolution of multicopper blue proteins. Cell Mol. Life Sci. 2005, 62, 2050-2066. [CrossRef]

17. Park, M.; Kim, M.; Kim, S.; Ha, B.; Ro, H.S. Differential expression of laccase genes in Pleurotus ostreatus and biochemical characterization of laccase isozymes produced in Pichia pastoris. Mycobiology 2015, 43, 280-287. [CrossRef]

18. Yang, J.; Wang, G.; Ng, T.B.; Lin, J.; Ye, X. Laccase Production and Differential Transcription of Laccase Genes in Cerrena sp. in Response to Metal Ions, Aromatic Compounds, and Nutrients. Front. Microbiol. 2015, 6, 1558. [CrossRef]

19. Yuan, X.; Tian, G.; Zhao, Y.; Zhao, L.; Wang, H.; Ng, T.B. Biochemical characteristics of three laccase isoforms from the basidiomycete Pleurotus nebrodensis. Molecules 2016, 21, E203. [CrossRef]

20. Karp, S.G.; Faraco, V.; Amore, A.; Birolo, L.; Giangrande, C.; Soccol, V.T.; Pandey, A.; Soccol, C.R. Characterization of laccase isoforms produced by Pleurotus ostreatus in solid state fermentation of sugarcane bagasse. Bioresour. Technol. 2012, 114, 735-739. [CrossRef]

21. Moiseenko, K.V.; Maloshenok, L.G.; Vasina, D.V.; Bruskin, S.A.; Tyazhelova, T.V.; Koroleva, O.V. Laccase multigene families in Agaricomycetes. J. Basic Microbiol. 2016, 56, 1392-1397. [CrossRef] [PubMed]

22. Sneath, P.H.A.; Sokal, R.R. Numerical Taxonomy; Freeman: San Francisco, CA, USA, 1973.

23. Felsenstein, J. Confidence limits on phylogenies: An approach using the bootstrap. Evol. Int. J. Org. Evol. 1985, 39, 783-791. [CrossRef] [PubMed] 
24. Schwarz, R.; Dayhoff, M. Matrices for detecting distant relationships. In Atlas of Protein Sequences; Dayhoff, M., Ed.; The National Biomedical Research Foundation: Silver Spring, MD, USA, 1979; pp. 353-358.

25. Kumar, S.; Stecher, G.; Tamura, K. MEGA7: Molecular evolutionary genetics analysis version 7.0 for bigger eatasets. Mol. Biol. Evol. 2016, 33, 1870-1874. [CrossRef] [PubMed]

26. Sitarz, A.K.; Mikkelsen, J.D.; Meyer, A.S. Structure, functionality and tuning up of laccases for lignocellulose and other industrial applications. Crit. Rev. Biotechnol. 2016, 36, 70-86. [CrossRef]

27. Giardina, P.; Faraco, V.; Pezzella, C.; Piscitelli, A.; Vanhulle, S.; Sannia, G. Laccases: A never-ending story. Cell Mol. Life Sci. 2010, 67, 369-385. [CrossRef] [PubMed]

28. Canas, A.I.; Camarero, S. Laccases and their natural mediators: Biotechnological tools for sustainable eco-friendly processes. Biotechnol. Adv. 2010, 28, 694-705. [CrossRef]

29. Munk, L.; Sitarz, A.K.; Kalyani, D.C.; Mikkelsen, J.D.; Meyer, A.S. Can laccases catalyze bond cleavage in lignin? Biotechnol. Adv. 2015, 33, 13-24. [CrossRef]

30. Kim, J.E.; Han, K.H.; Jin, J.; Kim, H.; Kim, J.C.; Yun, S.H.; Lee, Y.W. Putative polyketide synthase and laccase genes for biosynthesis of aurofusarin in Gibberella zeae. Appl. Environ. Microbiol. 2005, 71, 1701-1708. [CrossRef]

31. Dittmer, N.T.; Kanost, M.R. Insect multicopper oxidases: Diversity, properties, and physiological roles. Insect Biochem. Mol. Biol. 2010, 40, 179-188. [CrossRef]

32. Bao, W.; O'Malley D, M.; Whetten, R.; Sederoff, R.R. A laccase associated with lignification in loblolly pine xylem. Science 1993, 260, 672-674. [CrossRef]

33. Omalley, D.M.; Whetten, R.; Bao, W.L.; Chen, C.L.; Sederoff, R.R. The role of laccase in lignification. Plant. J. 1993, 4, 751-757. [CrossRef]

34. Chefetz, B.; Chen, Y.; Hadar, Y. Purification and characterization of laccase from Chaetomium thermophilium and its role in humification. Appl. Environ. Microbiol. 1998, 64, 3175-3179. [CrossRef] [PubMed]

35. Mikolasch, A.; Schauer, F. Fungal laccases as tools for the synthesis of new hybrid molecules and biomaterials. Appl. Microbiol. Biotechnol. 2009, 82, 605-624. [CrossRef] [PubMed]

36. Driouich, A.; Laine, A.C.; Vian, B.; Faye, L. Characterization and localization of laccase forms in stem and cell-cultures of sycamore. Plant J. 1992, 2, 13-24. [CrossRef]

37. Harakava, R. Genes encoding enzymes of the lignin biosynthesis pathway in Eucalyptus. Genet. Mol. Biol. 2005, 28, 601-607. [CrossRef]

38. Pourcel, L.; Routaboul, J.M.; Kerhoas, L.; Caboche, M.; Lepiniec, L.; Debeaujon, I. TRANSPARENT TESTA10 encodes a laccase-like enzyme involved in oxidative polymerization of flavonoids in Arabidopsis seed coat. Plant Cell 2005, 17, 2966-2980. [CrossRef]

39. Ranocha, P.; Chabannes, M.; Chamayou, S.; Danoun, S.; Jauneau, A.; Boudet, A.M.; Goffner, D. Laccase down-regulation causes alterations in phenolic metabolism and cell wall structure in poplar. Plant Physiol. 2002, 129, 145-155. [CrossRef]

40. Sugumaran, M.; Giglio, L.; Kundzicz, H.; Saul, S.; Semensi, V. Studies on the enzymes involved in puparial cuticle sclerotization in Drosophila melanogaster. Arch. Insect. Biochem. Physiol. 1992, 19, 271-283. [CrossRef]

41. Arakane, Y.; Muthukrishnan, S.; Beeman, R.W.; Kanost, M.R.; Kramer, K.J. Laccase 2 is the phenoloxidase gene required for beetle cuticle tanning. Proc. Natl. Acad. Sci. USA 2005, 102, 11337-11342. [CrossRef]

42. Kramer, K.J.; Kanost, M.R.; Hopkins, T.L.; Jiang, H.B.; Zhu, Y.C.; Xu, R.D.; Kerwin, J.L.; Turecek, F. Oxidative conjugation of catechols with proteins in insect skeletal systems. Tetrahedron 2001, 57, 385-392. [CrossRef]

43. Bell, A.A.; Wheeler, M.H. Biosynthesis and functions of fungal melanins. Annu. Rev. Phytopathol. 1986, 24, 411-451. [CrossRef]

44. Tsai, H.F.; Wheeler, M.H.; Chang, Y.C.; Kwon-Chung, K.J. A developmentally regulated gene cluster involved in conidial pigment biosynthesis in Aspergillus fumigatus. J. Bacteriol. 1999, 181, 6469-6477. [CrossRef] [PubMed]

45. Frases, S.; Salazar, A.; Dadachova, E.; Casadevall, A. Cryptococcus neoformans can utilize the bacterial melanin precursor homogentisic acid for fungal melanogenesis. Appl. Environ. Microbiol. 2007, 73, 615-621. [CrossRef] [PubMed]

46. Guillen, F.; Gomez-Toribio, V.; Martinez, M.J.; Martinez, A.T. Production of hydroxyl radical by the synergistic action of fungal laccase and aryl alcohol oxidase. Arch. Biochem. Biophys. 2000, 383, 142-147. [CrossRef] 
47. Wei, D.S.; Houtman, C.J.; Kapich, A.N.; Hunt, C.G.; Cullen, D.; Hammel, K.E. Laccase and its role in production of extracellular reactive oxygen species during wood decay by the brown rot basidiomycete Postia placenta. Appl. Environ. Microbiol. 2010, 76, 2091-2097. [CrossRef]

48. Bajpai, P. Application of enzymes in the pulp and paper industry. Biotechnol. Progr. 1999, 15, $147-157$. [CrossRef]

49. Kawai, S.; Umezawa, T.; Higuchi, T. Degradation mechanisms of phenolic b-1 lignin substructure model compounds by laccase of Coriolus versicolor. Arch. Biochem. Biophys. 1988, 262, 99-110. [CrossRef]

50. Rico, A.; Rencoret, J.; Del Rio, J.C.; Martinez, A.T.; Gutierrez, A. Pretreatment with laccase and a phenolic mediator degrades lignin and enhances saccharification of Eucalyptus feedstock. Biotechnol. Biofuels 2014, 7, 6. [CrossRef]

51. Rochefort, D.; Leech, D.; Bourbonnais, R. Electron transfer mediator systems for bleaching of paper pulp. Green Chem. 2004, 6, 14-24. [CrossRef]

52. Westereng, B.; Cannella, D.; Agger, J.W.; Jorgensen, H.; Andersen, M.L.; Eijsink, V.G.H.; Felby, C. Enzymatic cellulose oxidation is linked to lignin by long-range electron transfer. Sci. Rep. 2015, 5. [CrossRef]

53. D'Acunzo, F.; Galli, C.; Gentili, P.; Sergi, F. Mechanistic and steric issues in the oxidation of phenolic and non-phenolic compounds by laccase or laccase-mediator systems. The case of bifunctional substrates. N. J. Chem. 2006, 30, 583-591. [CrossRef]

54. Bugg, T.D.; Ahmad, M.; Hardiman, E.M.; Rahmanpour, R. Pathways for degradation of lignin in bacteria and fungi. Nat. Prod. Rep. 2011, 28, 1883-1896. [CrossRef] [PubMed]

55. Masai, E.; Katayama, Y.; Fukuda, M. Genetic and biochemical investigations on bacterial catabolic pathways for lignin-derived aromatic compounds. Biosci. Biotechnol. Biochem. 2007, 71, 1-15. [CrossRef]

56. Sharma, K.K.; Kuhad, R.C. An evidence of laccases in archaea. Indian J. Microbiol. 2009, 49, 142-150. [CrossRef] [PubMed]

57. Mayer, A.M. Polyphenol oxidases in plants and fungi: Going places? A review. Phytochemistry 2006, 67, 2318-2331. [CrossRef]

58. Liu, L.; Dean, J.F.; Friedman, W.E.; Eriksson, K.E.L. A laccase-like phenoloxidase is correlated with lignin biosynthesis in Zinnia elegans stem tissues. Plant. J. 1994, 6, 213-224. [CrossRef]

59. Sanchez-Ferrer, A.; Rodriguez-Lopez, J.N.; Garcia-Canovas, F.; Garcia-Carmona, F. Tyrosinase: A comprehensive review of its mechanism. Biochim. Biophys. Acta 1995, 1247, 1-11. [CrossRef]

60. Taranto, F.; Pasqualone, A.; Mangini, G.; Tripodi, P.; Miazzi, M.M.; Pavan, S.; Montemurro, C. Polyphenol oxidases in crops: Biochemical, physiological and genetic aspects. Int. J. Mol. Sci. 2017, 18. [CrossRef]

61. Faccio, G.; Kruus, K.; Saloheimo, M.; Thöny-Meyer, L. Bacterial tyrosinases and their applications. Process. Biochem. 2012, 47, 1749-1760. [CrossRef]

62. Aniszewski, T.; Lieberei, R.; Gulewicz, K. Research on catecholases, laccases and cresolases in plants. Recent progress and future needs. Acta. Biol. Crac. Ser. Bot. 2008, 50, 7-18.

63. Jiménez, M.; Kameyama, K.; Maloy, W.L.; Tomita, Y.; Hearing, V.J. Mammalian tyrosinase: Biosynthesis, processing, and modulation by melanocyte-stimulating hormone. Proc. Natl. Acad. Sci. 1988, 85, 3830-3834. [CrossRef] [PubMed]

64. Chisari, M.; Barbagallo, R.N.; Spagna, G. Characterization of polyphenol oxidase and peroxidase and influence on browning of cold stored strawberry fruit. J. Agric. Food Chem. 2007, 55, 3469-3476. [CrossRef] [PubMed]

65. Pourcel, L.; Routaboul, J.-M.; Cheynier, V.; Lepiniec, L.; Debeaujon, I. Flavonoid oxidation in plants: From biochemical properties to physiological functions. Trends Plant. Sci. 2007, 12, 29-36. [CrossRef] [PubMed]

66. Molitor, C.; Mauracher, S.G.; Rompel, A. Aurone synthase is a catechol oxidase with hydroxylase activity and provides insights into the mechanism of plant polyphenol oxidases. Proc. Natl. Acad. Sci. 2016, 113, E1806-E1815. [CrossRef] [PubMed]

67. Walker, J.R.; Ferrar, P.H. Diphenol oxidases, enzyme-catalysed browning and plant disease resistance. Biotechnol. Genet. Eng. Rev. 1998, 15, 457-498. [CrossRef] [PubMed]

68. Constabel, C.P.; Barbehenn, R. Defensive roles of polyphenol oxidase in plants. In Induced Plant Resistance to Herbivory; Springer: Berlin, Germany, 2008; pp. 253-270. 
69. War, A.R.; Paulraj, M.G.; Ahmad, T.; Buhroo, A.A.; Hussain, B.; Ignacimuthu, S.; Sharma, H.C. Mechanisms of plant defense against insect herbivores. Plant Signal. Behav. 2012, 7, 1306-1320. [CrossRef]

70. Sugumaran, M.; Nellaiappan, K.; Valivittan, K. A new mechanism for the control of phenoloxidase activity: Inhibition and complex formation with quinone isomerase. Arch. Biochem. Biophys. 2000, 379, 252-260. [CrossRef]

71. Sugumaran, M. Comparative biochemistry of eumelanogenesis and the protective roles of phenoloxidase and melanin in insects. Pigment. Cell Res. 2002, 15, 2-9. [CrossRef]

72. Hu, Y.; Wang, Y.; Deng, J.; Jiang, H. The structure of a prophenoloxidase (PPO) from Anopheles gambiae provides new insights into the mechanism of PPO activation. BMC Biol. 2016, 14, 2. [CrossRef]

73. Veluthakkal, R.; Dasgupta, M.G. Pathogenesis-related genes and proteins in forest tree species. Trees 2010, 24, 993-1006. [CrossRef]

74. Almagro, L.; Ros, L.G.; Belchi-Navarro, S.; Bru, R.; Barceló, A.R.; Pedreño, M. Class III peroxidases in plant defence reactions. J. Exp. Bot. 2009, 60, 377-390. [CrossRef] [PubMed]

75. Fuerst, E.P.; Okubara, P.A.; Anderson, J.V.; Morris, C.F. Polyphenol oxidase as a biochemical seed defense mechanism. Front. Plant Sci. 2014, 5, 689. [CrossRef] [PubMed]

76. Selinheimo, E.; NiEidhin, D.; Steffensen, C.; Nielsen, J.; Lomascolo, A.; Halaouli, S.; Record, E.; O’Beirne, D.; Buchert, J.; Kruus, K. Comparison of the characteristics of fungal and plant tyrosinases. J. Biotechnol. 2007, 130, 471-480. [CrossRef] [PubMed]

77. Solano, F. Melanins: Skin pigments and much more-types, structural models, biological functions, and formation routes. N. J. Sci. 2014, 2014. [CrossRef]

78. McMahon, A.M.; Doyle, E.M.; Brooks, S.; O'Connor, K.E. Biochemical characterisation of the coexisting tyrosinase and laccase in the soil bacterium Pseudomonas putida F6. Enzym. Microb. Technol. 2007, 40, 1435-1441. [CrossRef]

79. Eisenman, H.C.; Casadevall, A. Synthesis and assembly of fungal melanin. Appl. Microbiol. Biotechnol. 2012, 93, 931-940. [CrossRef]

80. Sjoblad, R.; Bollag, J. Oxidative coupling of aromatic compounds by enzymes from soil microorganisms. Soil Biochem. 1981, 5, 113-152.

81. Lundell, T.K.; Mäkelä, M.R.; Hildén, K. Lignin-modifying enzymes in filamentous basidiomycetes-ecological, functional and phylogenetic review. J. Basic Microbiol. 2010, 50, 5-20. [CrossRef]

82. Sinsabaugh, R.L. Phenol oxidase, peroxidase and organic matter dynamics of soil. Soil Biol. Biochem. 2010, 42, 391-404. [CrossRef]

83. Alexandre, G.; Zhulin, I.B. Laccases are widespread in bacteria. Trends Biotechnol. 2000, 18, 41-42. [CrossRef]

84. Claus, H. Laccases and their occurrence in prokaryotes. Arch. Microbiol. 2003, 179, 145-150. [CrossRef] [PubMed]

85. Givaudan, A.; Effosse, A.; Faure, D.; Potier, P.; Bouillant, M.L.; Bally, R. Polyphenol oxidase in Azospirillum lipoferum isolated from rice rhizosphere - evidence for laccase activity in nonmotile strains of Azospirillum lipoferum. FEMS Microbiol. Lett. 1993, 108, 205-210. [CrossRef]

86. Diamantidis, G.; Effosse, A.; Potier, P.; Bally, R. Purification and characterization of the first bacterial laccase in the rhizospheric bacterium Azospirillum lipoferum. Soil Biol. Biochem. 2000, 32, 919-927. [CrossRef]

87. Reiss, R.; Ihssen, J.; Thöny-Meyer, L. Bacillus pumilus laccase: A heat stable enzyme with a wide substrate spectrum. BMC Biotechnol. 2011, 11, 9. [CrossRef]

88. Checinska, A.; Burbank, M.; Paszczynski, A.J. Protection of Bacillus pumilus spores by catalases. Appl. Environ. Microbiol. 2012, 78, 6413-6422. [CrossRef]

89. Hullo, M.F.; Moszer, I.; Danchin, A.; Martin-Verstraete, I. CotA of Bacillus subtilis is a copper-dependent laccase. J. Bacteriol. 2001, 183, 5426-5430. [CrossRef]

90. Koschorreck, K.; Richter, S.M.; Ene, A.B.; Roduner, E.; Schmid, R.D.; Urlacher, V.B. Cloning and characterization of a new laccase from Bacillus licheniformis catalyzing dimerization of phenolic acids. Appl. Microbiol. Biotechnol. 2008, 79, 217-224. [CrossRef]

91. Suzuki, T.; Endo, K.; Ito, M.; Tsujibo, H.; Miyamoto, K.; Inamori, Y. A thermostable laccase from Streptomyces lavendulae REN-7: Purification, characterization, nucleotide sequence, and expression. Biosci. Biotechnol. Biochem. 2003, 67, 2167-2175. [CrossRef]

92. Endo, K.; Hayashi, Y.; Hibi, T.; Hosono, K.; Beppu, T.; Ueda, K. Enzymological characterization of EpoA, a laccase-like phenol oxidase produced by Streptomyces griseus. J. Biochem. 2003, 133, 671-677. [CrossRef] 
93. Solano, F.; Lucas-Elío, P.; López-Serrano, D.; Fernández, E.; Sanchez-Amat, A. Dimethoxyphenol oxidase activity of different microbial blue multicopper proteins. FEMS Microbiol. Lett. 2001, 204, 175-181. [CrossRef]

94. Miyazaki, K. A hyperthermophilic laccase from Thermus thermophilus HB27. Extremophiles 2005, 9, 415-425. [CrossRef]

95. Castro-Sowinski, S.; Martinez-Drets, G.; Okon, Y. Laccase activity in melanin-producing strains of Sinorhizobium meliloti. FEMS Microbiol. Lett. 2002, 209, 119-125. [CrossRef]

96. Palanisami, S.; Saha, S.K.; Lakshmanan, U. Laccase and polyphenol oxidase activities of marine cyanobacteria: A study with Poly R-478 decolourization. World J. Microbiol. Biotechnol. 2010, 26, 63-69. [CrossRef]

97. Uthandi, S.; Saad, B.; Humbard, M.A.; Maupin-Furlow, J.A. LccA, an archaeal laccase secreted as a highly stable glycoprotein into the extracellular medium by Haloferax volcanii. Appl. Environ. Microbiol. 2010, 76, 733-743. [CrossRef]

98. Sanchez-Amat, A.; Solano, F. A pluripotent polyphenol oxidase from the melanogenic marine Alteromonas sp shares catalytic capabilities of tyrosinases and laccases. Biochem. Biophys. Res. Commun. 1997, 240, 787-792. [CrossRef]

99. Fernandes, A.T.; Soares, C.M.; Pereira, M.M.; Huber, R.; Grass, G.; Martins, L.O. A robust metallo-oxidase from the hyperthermophilic bacterium Aquifex aeolicus. FEBS J. 2007, 274, 2683-2694. [CrossRef]

100. Bains, J.; Capalash, N.; Sharma, P. Laccase from a non-melanogenic, alkalotolerant gamma-proteobacterium JB isolated from industrial wastewater drained soil. Biotechnol. Lett. 2003, 25, 1155-1159. [CrossRef]

101. Martins, L.O.; Soares, C.M.; Pereira, M.M.; Teixeira, M.; Costa, T.; Jones, G.H.; Henriques, A.O. Molecular and biochemical characterization of a highly stable bacterial laccase that occurs as a structural component of the Bacillus subtilis endospore coat. J. Biol. Chem. 2002, 277, 18849-18859. [CrossRef]

102. Alexandre, G.; Bally, R.; Taylor, B.L.; Zhulin, I.B. Loss of cytochrome c oxidase activity and acquisition of resistance to quinone analogs in a laccase-positive variant of Azospirillum lipoferum. J. Bacteriol. 1999, 181, 6730-6738. [CrossRef]

103. Dubé, E.; Shareck, F.; Hurtubise, Y.; Daneault, C.; Beauregard, M. Homologous cloning, expression, and characterisation of a laccase from Streptomyces coelicolor and enzymatic decolourisation of an indigo dye. Appl. Microbiol. Biotechnol. 2008, 79, 597-603. [CrossRef]

104. Sondhi, S.; Sharma, P.; Saini, S.; Puri, N.; Gupta, N. Purification and characterization of an extracellular, thermo-alkali-stable, metal tolerant laccase from Bacillus tequilensis SN4. PLoS ONE 2014, 9, e96951. [CrossRef]

105. Claus, H. Copper-containing oxidases: Occurrence in soil microorganisms, properties, and applications. In Soil Heavy Metals; Springer: Berlin/Heidelberg, Germany, 2010; pp. 281-313.

106. Machczynski, M.C.; Vijgenboom, E.; Samyn, B.; Canters, G.W. Characterization of SLAC: A small laccase from Streptomyces coelicolor with unprecedented activity. Protein Sci. 2004, 13, 2388-2397. [CrossRef]

107. Niladevi, K.; Sheejadevi, P.; Prema, P. Strategies for enhancing laccase yield from Streptomyces psammoticus and its role in mediator-based decolorization of azo dyes. Appl. Biochem. Biotechnol. 2008, 151, 9-19. [CrossRef]

108. Gunne, M.; Hoppner, A.; Hagedoorn, P.L.; Urlacher, V.B. Structural and redox properties of the small laccase Ssl1 from Streptomyces sviceus. FEBS J. 2014, 281, 4307-4318. [CrossRef]

109. Skalova, T.; Dohnalek, J.; Ostergaard, L.H.; Ostergaard, P.R.; Kolenko, P.; Duskova, J.; Stepankova, A.; Hasek, J. The structure of the small laccase from Streptomyces coelicolor reveals a link between laccases and nitrite reductases. J. Mol. Biol. 2009, 385, 1165-1178. [CrossRef]

110. Nothaft, H.; Szymanski, C.M. Protein glycosylation in bacteria: Sweeter than ever. Nat. Rev. Microbiol. 2010, 8, 765-778. [CrossRef]

111. Pawlik, A.; Wojcik, M.; Rulka, K.; Motyl-Gorzel, K.; Osinska-Jaroszuk, M.; Wielbo, J.; Marek-Kozaczuk, M.; Skorupska, A.; Rogalski, J.; Janusz, G. Purification and characterization of laccase from Sinorhizobium meliloti and analysis of the lacc gene. Int. J. Biol. Macromol. 2016, 92, 138-147. [CrossRef]

112. Fernandes, A.T.; Damas, J.M.; Todorovic, S.; Huber, R.; Baratto, M.C.; Pogni, R.; Soares, C.M.; Martins, L.O. The multicopper oxidase from the archaeon Pyrobaculum aerophilum shows nitrous oxide reductase activity. Febs. J. 2010, 277, 3176-3189. [CrossRef]

113. Melo, E.P.; Fernandes, A.T.; Durao, P.; Martins, L.O. Insight into stability of CotA laccase from the spore coat of Bacillus subtilis. Biochem. Soc. Trans. 2007, 35, 1579-1582. [CrossRef]

114. Gunne, M.; Urlacher, V.B. Characterization of the alkaline laccase Ssl1 from Streptomyces sviceus with unusual properties discovered by genome mining. PLoS ONE 2012, 7, e52360. [CrossRef] 
115. Molina-Guijarro, J.M.; Perez, J.; Munoz-Dorado, J.; Guillen, F.; Moya, R.; Hernandez, M.; Arias, M.E. Detoxification of azo dyes by a novel $\mathrm{pH}$-versatile, salt-resistant laccase from Streptomyces ipomoea. Int. Microbiol. Off. J. Span. Soc. Microbiol. 2009, 12, 13-21. [CrossRef]

116. Sharma, K.K.; Kuhad, R.C. Laccase: Enzyme revisited and function redefined. Indian J. Microbiol. 2008, 48, 309-316. [CrossRef] [PubMed]

117. Martins, L.O.; Durao, P.; Brissos, V.; Lindley, P.F. Laccases of prokaryotic origin: Enzymes at the interface of protein science and protein technology. Cell Mol. Life Sci. 2015, 72, 911-922. [CrossRef] [PubMed]

118. Sharma, P.; Goel, R.; Capalash, N. Bacterial laccases. World J. Microb. Biot. 2007, 23, 823-832. [CrossRef]

119. Singh, G.; Bhalla, A.; Kaur, P.; Capalash, N.; Sharma, P. Laccase from prokaryotes: A new source for an old enzyme. Rev. Environ. Sci. Biotechnol. 2011, 10, 309-326. [CrossRef]

120. Baldrian, P. Fungal laccases - occurrence and properties. FEMS Microbiol. Rev. 2006, 30, 215-242. [CrossRef]

121. Brown, M.E.; Chang, M.C.Y. Exploring bacterial lignin degradation. Curr. Opin. Chem. Biol. 2014, $19,1-7$. [CrossRef]

122. De Gonzalo, G.; Colpa, D.I.; Habib, M.H.M.; Fraaije, M.W. Bacterial enzymes involved in lignin degradation. J. Biotechnol. 2016, 236, 110-119. [CrossRef]

123. Faure, D.; Bouillant, M.L.; Jacoud, C.; Bally, R. Phenolic derivatives related to lignin metabolism as substrates for Azospirillum laccase activity. Phytochemistry 1996, 42, 357-359. [CrossRef]

124. Endo, K.; Hosono, K.; Beppu, T.; Ueda, K. A novel extracytoplasmic phenol oxidase of Streptomyces: Its possible involvement in the onset of morphogenesis. Microbiology 2002, 148, 1767-1776. [CrossRef]

125. Arias, M.E.; Arenas, M.; Rodriguez, J.; Soliveri, J.; Ball, A.S.; Hernandez, M. Kraft pulp biobleaching and mediated oxidation of a nonphenolic substrate by laccase from Streptomyces cyaneus CECT 3335. Appl. Environ. Microbiol. 2003, 69, 1953-1958. [CrossRef] [PubMed]

126. Freeman, J.C.; Nayar, P.G.; Begley, T.P.; Villafranca, J.J. Stoichiometry and spectroscopic identity of copper centers in phenoxazinone synthase: A new addition to the blue copper oxidase family. Biochemistry 1993, 32, 4826-4830. [CrossRef] [PubMed]

127. Mohammadian, M.; Fathi-Roudsari, M.; Mollania, N.; Badoei-Dalfard, A.; Khajeh, K. Enhanced expression of a recombinant bacterial laccase at low temperature and microaerobic conditions: Purification and biochemical characterization. J. Ind. Microbiol. Biotechnol. 2010, 37, 863-869. [CrossRef] [PubMed]

128. Pandey, N.K.; Aronson, A.I. Properties of the Bacillus subtilis spore coat. J. Bacteriol. 1979, 137, 1208-1218. [CrossRef]

129. Francis, C.A.; Tebo, B.M. cumA multicopper oxidase genes from diverse Mn(II)-oxidizing and non-Mn(II)-oxidizing Pseudomonas strains. Appl. Environ. Microbiol. 2001, 67, 4272-4278. [CrossRef]

130. Kim, C.; Lorenz, W.W.; Hoopes, J.T.; Dean, J.F.D. Oxidation of phenolate siderophores by the multicopper oxidase encoded by the Escherichia coli yacK Gene. J. Bacteriol. 2001, 183, 4866-4875. [CrossRef]

131. Roberts, S.A.; Weichsel, A.; Grass, G.; Thakali, K.; Hazzard, J.T.; Tollin, G.; Rensing, C.; Montfort, W.R. Crystal structure and electron transfer kinetics of $\mathrm{CueO}$, a multicopper oxidase required for copper homeostasis in Escherichia coli. Proc. Natl Acad. Sci. USA 2002, 99, 2766-2771. [CrossRef]

132. Mellano, M.A.; Cooksey, D.A. Nucleotide sequence and organization of copper resistance genes from Pseudomonas syringae pv. tomato. J. Bacteriol. 1988, 170, 2879-2883. [CrossRef]

133. Ansari, M.K.A.; Khatib, U.M.; Owens, G.; Fatma, T. Evaluation of methyl red tolerant cyanobacteria for simultaneous laccase production and dye decolorization. Int. J. Waste Resour. 2016, 6, 2252-5211. [CrossRef]

134. Afreen, S.; Anwer, R.; Singh, R.K.; Fatma, T. Extracellular laccase production and its optimization from Arthrospira maxima catalyzed decolorization of synthetic dyes. Saudi J. Biol. Sci. 2018, 25, 1446-1453. [CrossRef]

135. Otto, B.; Schlosser, D. First laccase in green algae: Purification and characterization of an extracellular phenol oxidase from Tetracystis aeria. Planta 2014, 240, 1225-1236. [CrossRef]

136. Wang, J.; Feng, J.; Jia, W.; Chang, S.; Li, S.; Li, Y. Lignin engineering through laccase modification: A promising field for energy plant improvement. Biotechnol. Biofuels 2015, 8, 145. [CrossRef]

137. Harvey, B.M. Laccases in Higher Plants. Master's Thesis, University of Canterbury, Christchurch, New Zealand, 1997.

138. Thurston, C.F. The structure and function of fungal laccases. Microbiology 1994, 140, 19-26. [CrossRef]

139. Bligny, R.; Douce, R. Excretion of laccase by sycamore (Acer pseudoplatanus L) cells.1. purification and properties of the enzyme. Biochem. J. 1983, 209, 489-496. [CrossRef] [PubMed] 
140. Sato, Y.; Bao, W.L.; Sederoff, R.; Whetten, R. Molecular cloning and expression of eight laccase cDNAs in loblolly pine (Pinus taeda). J. Plant Res. 2001, 114, 147-155. [CrossRef]

141. Ranocha, P.; McDougall, G.; Hawkins, S.; Sterjiades, R.; Borderies, G.; Stewart, D.; Cabanes-Macheteau, M.; Boudet, A.M.; Goffner, D. Biochemical characterization, molecular cloning and expression of laccases - a divergent gene family - in poplar. Eur. J. Biochem. 1999, 259, 485-495. [CrossRef] [PubMed]

142. Richardson, A.; McDougall, G.J. A laccase-type polyphenol oxidase from lignifying xylem of tobacco. Phytochemistry 1997, 44, 229-235. [CrossRef]

143. Wosilait, W.D.; Nason, A.; Terrell, A.J. Pyridine nucleotide-quinone reductase.2. role in electron transport. J. Biol. Chem. 1954, 206, 271-282.

144. McCaig, B.C.; Meagher, R.B.; Dean, J.F. Gene structure and molecular analysis of the laccase-like multicopper oxidase (LMCO) gene family in Arabidopsis thaliana. Planta 2005, 221, 619-636. [CrossRef]

145. Berthet, S.; Thevenin, J.; Baratiny, D.; Demont-Caulet, N.; Debeaujon, I.; Bidzinski, P.; Leple, J.C.; Huis, R.; Hawkins, S.; Gomez, L.D.; et al. Role of plant laccases in lignin polymerization. Adv. Bot. Res. 2012, 61, 145. [CrossRef]

146. Polak, J.; Jarosz-Wilkołazka, A. Reakcje katalizowane przez lakazę-mechanizm i zastosowanie w biotechnologii. Biotechnologia 2007, 4, 82-94.

147. Mayer, A.M.; Staples, R.C. Laccase: New functions for an old enzyme. Phytochemistry 2002, 60, 551-565. [CrossRef]

148. Hoopes, J.T.; Dean, J.F. Ferroxidase activity in a laccase-like multicopper oxidase from Liriodendron tulipifera. Plant. Physiol. Biochem. 2004, 42, 27-33. [CrossRef] [PubMed]

149. Nakamura, T. Purification and physico-chemical properties of laccase. Biochim. Biophys. Acta. 1958, 30, 44-52. [CrossRef]

150. Sterjiades, R.; Dean, J.F.; Eriksson, K.E. Laccase from sycamore maple (Acer pseudoplatanus) polymerizes monolignols. Plant Physiol. 1992, 99, 1162-1168. [CrossRef] [PubMed]

151. Hoegger, P.J.; Kilaru, S.; James, T.Y.; Thacker, J.R.; Kues, U. Phylogenetic comparison and classification of laccase and related multicopper oxidase protein sequences. FEBS J. 2006, 273, 2308-2326. [CrossRef] [PubMed]

152. Martinez, A.T.; Speranza, M.; Ruiz-Duenas, F.J.; Ferreira, P.; Camarero, S.; Guillen, F.; Martinez, M.J.; Gutierrez, A.; del Rio, J.C. Biodegradation of lignocellulosics: Microbial chemical, and enzymatic aspects of the fungal attack of lignin. Int. Microbiol. Off. J. Span. Soc. Microbiol. 2005, 8, 195-204.

153. Ruiz-Duenas, F.J.; Martinez, A.T. Microbial degradation of lignin: How a bulky recalcitrant polymer is efficiently recycled in nature and how we can take advantage of this. Microb. Biotechnol. 2009, 2, 164-177. [CrossRef]

154. Gianfreda, L.; Xu, F.; Bollag, J.-M. Laccases: A useful group of oxidoreductive enzymes. Bioremediat. J. 1999, 3, 1-26. [CrossRef]

155. Voriskova, J.; Baldrian, P. Fungal community on decomposing leaf litter undergoes rapid successional changes. ISME J. 2013, 7, 477-486. [CrossRef]

156. Barlocher, F.; Boddy, L. Aquatic fungal ecology - How does it differ from terrestrial? Fungal Ecol. 2016, 19, 5-13. [CrossRef]

157. Blackwood, C.B.; Waldrop, M.P.; Zak, D.R.; Sinsabaugh, R.L. Molecular analysis of fungal communities and laccase genes in decomposing litter reveals differences among forest types but no impact of nitrogen deposition. Environ. Microbiol. 2007, 9, 1306-1316. [CrossRef] [PubMed]

158. Das, M.; Royer, T.V.; Leff, L.G. Diversity of fungi, bacteria, and actinomycetes on leaves decomposing in a stream. Appl. Environ. Microbiol. 2007, 73, 756-767. [CrossRef] [PubMed]

159. Sole, M.; Kellner, H.; Brock, S.; Buscot, F.; Schlosser, D. Extracellular laccase activity and transcript levels of putative laccase genes during removal of the xenoestrogen technical nonylphenol by the aquatic hyphomycete Clavariopsis aquatica. FEMS Microbiol. Lett. 2008, 288, 47-54. [CrossRef] [PubMed]

160. Martin, C.; Corvini, P.F.; Vinken, R.; Junghanns, C.; Krauss, G.; Schlosser, D. Quantification of the influence of extracellular laccase and intracellular reactions on the isomer-specific biotransformation of the xenoestrogen technical nonylphenol by the aquatic hyphomycete Clavariopsis aquatica. Appl. Environ. Microbiol. 2009, 75, 4398-4409. [CrossRef] [PubMed]

161. Abdel-Raheem, A.M. Laccase activity of lignicolous aquatic hyphomycetes isolated from the River Nile in Egypt. Mycopathologia 1997, 139, 145-150. [CrossRef] [PubMed] 
162. Junghanns, C.; Parra, R.; Keshavarz, T.; Schlosser, D. Towards higher laccase activities produced by aquatic ascomycetous fungi through combination of elicitors and an alternative substrate. Eng. Life Sci. 2008, 8, 277-285. [CrossRef]

163. Shevchenko, S.M.; Bailey, G.W. Life after death: Lignin-humic relationships reexamined. Crit. Rev. Environ. Sci. Technol. 1996, 26, 95-153. [CrossRef]

164. Hofrichter, M.; Fritsche, W. Depolymerization of low rank coal by extracellular fungal enzyme systems.1. Screening for low rank-coal-depolymerizing activities. Appl. Microbiol. Biotechnol. 1996, 46, 220-225. [CrossRef]

165. Grinhut, T.; Hadar, Y.; Chen, Y. Degradation and transformation of humic substances by saprotrophic fungi: Processes and mechanisms. Fungal Biol. Rev. 2007, 21, 179-189. [CrossRef]

166. Feng, S.Z.; Su, Y.R.; Dong, M.Z.; He, X.Y.; Kumaresan, D.; O’Donnell, A.; Wu, J.S.; Chen, X.B. Laccase activity is proportional to the abundance of bacterial laccase-like genes in soil from subtropical arable land. World J. Microbiol. Biotechnol. 2015, 31, 2039-2045. [CrossRef] [PubMed]

167. Polak, J. Structure/Redox potential relationship of simple organic compounds as potential precursors of dyes for laccase-mediated transformation. Biotechnol. Progr. 2012, 28, 93-102. [CrossRef] [PubMed]

168. Savoie, J.M.; Mata, G. Antagonistic action of Trichoderma sp. hyphae to Lentinula edodes hyphae changes lignocellulolytic activities during cultivation in wheat straw. World J. Microb. Biotechnol. 1999, 15, 369-373. [CrossRef]

169. Velazquez-Cedeno, M.; Farnet, A.M.; Billette, C.; Mata, G.; Savoie, J.M. Interspecific interactions with Trichoderma longibrachiatum induce Pleurotus ostreatus defence reactions based on the production of laccase isozymes. Biotechnol. Lett. 2007, 29, 1583-1590. [CrossRef]

170. Flores, C.; Vidal, C.; Trejo-Hernandez, M.R.; Galindo, E.; Serrano-Carre, L. Selection of Trichoderma strains capable of increasing laccase production by Pleurotus ostreatus and Agaricus bisporus in dual cultures. J. Appl. Microbiol. 2009, 106, 249-257. [CrossRef]

171. Sjaarda, C.P.; Abubaker, K.S.; Castle, A.J. Induction of lcc2 expression and activity by Agaricus bisporus provides defence against Trichoderma aggressivum toxic extracts. Microb. Biotechnol. 2015, 8, 918-929. [CrossRef]

172. Lakshmanan, D.; Sadasivan, C. Trichoderma viride laccase plays a crucial role in defense mechanism against antagonistic organisms. Front. Microbiol. 2016, 7. [CrossRef]

173. Schouten, A.; Maksimova, O.; Cuesta-Arenas, Y.; van den Berg, G.; Raaijmakers, J.M. Involvement of the $\mathrm{ABC}$ transporter BcAtrB and the laccase BcLCC2 in defence of Botrytis cinerea against the broad-spectrum antibiotic 2,4-diacetylphloroglucinol. Environ. Microbiol. 2008, 10, 1145-1157. [CrossRef]

174. Eggert, C.; Temp, U.; Dean, J.F.D.; Eriksson, K.E.L. Laccase-mediated formation of the phenoxazinone derivative, cinnabarinic acid. FEBS Lett. 1995, 376, 202-206. [CrossRef]

175. Eggert, C. Laccase-catalyzed formation of cinnabarinic acid is responsible for antibacterial activity of Pycnoporus cinnabarinus. Microbiol. Res. 1997, 152, 315-318. [CrossRef]

176. Nosanchuk, J.D.; Casadevall, A. The contribution of melanin to microbial pathogenesis. Cell. Microbiol. 2003, 5, 203-223. [CrossRef]

177. Goldman, D.L.; Khine, H.; Abadi, J.; Lindenberg, D.J.; Pirofski, L.; Niang, R.; Casadevall, A. Serologic evidence for Cryptococcus neoformans infection in early childhood. Pediatrics 2001, 107, E66. [CrossRef]

178. Erickson, T.; Liu, L.; Gueyikian, A.; Zhu, X.; Gibbons, J.; Williamson, P.R. Multiple virulence factors of Cryptococcus neoformans are dependent on VPH1. Mol. Microbiol. 2001, 42, 1121-1131. [CrossRef]

179. Jacobson, E.S.; Emery, H.S. Catecholamine uptake, melanization, and oxygen toxicity in Cryptococcus neoformans. J. Bacteriol. 1991, 173, 401-403. [CrossRef]

180. Polacheck, I.; Hearing, V.J.; Kwon-Chung, K.J. Biochemical studies of phenoloxidase and utilization of catecholamines in Cryptococcus neoformans. J. Bacteriol. 1982, 150, 1212-1220. [CrossRef]

181. Salas, S.D.; Bennett, J.E.; Kwon-Chung, K.J.; Perfect, J.R.; Williamson, P.R. Effect of the laccase gene CNLAC1, on virulence of Cryptococcus neoformans. J. Exp. Med. 1996, 184, 377-386. [CrossRef]

182. Wang, Y.; Aisen, P.; Casadevall, A. Cryptococcus neoformans melanin and virulence: Mechanism of action. Infect. Immun. 1995, 63, 3131-3136. [CrossRef]

183. Williamson, P.R. Biochemical and molecular characterization of the diphenol oxidase of Cryptococcus neoformans: Identification as a laccase. J. Bacteriol. 1994, 176, 656-664. [CrossRef] 
184. Williamson, P.R.; Wakamatsu, K.; Ito, S. Melanin biosynthesis in Cryptococcus neoformans. J. Bacteriol. 1998, 180, 1570-1572. [CrossRef]

185. Lee, S.C.; Dickson, D.W.; Casadevall, A. Pathology of cryptococcal meningoencephalitis: Analysis of 27 patients with pathogenetic implications. Hum. Pathol. 1996, 27, 839-847. [CrossRef]

186. Liu, L.; Tewari, R.P.; Williamson, P.R. Laccase protects Cryptococcus neoformans from antifungal activity of alveolar macrophages. Infect. Immun. 1999, 67, 6034-6039. [CrossRef] [PubMed]

187. Zhu, X.D.; Gibbons, J.; Garcia-Rivera, J.; Casadevall, A.; Williamson, P.R. Laccase of Cryptococcus neoformans is a cell wall-associated virulence factor. Infect. Immun. 2001, 69, 5589-5596. [CrossRef] [PubMed]

188. Sapmak, A.; Kaewmalakul, J.; Nosanchuk, J.D.; Vanittanakom, N.; Andrianopoulos, A.; Pruksaphon, K.; Youngchim, S. Talaromyces marneffei laccase modifies THP-1 macrophage responses. Virulence 2016, 7, 702-717. [CrossRef]

189. Sapmak, A.; Boyce, K.J.; Andrianopoulos, A.; Vanittanakom, N. The pbrB gene encodes a laccase required for DHN-melanin synthesis in conidia of Talaromyces (Penicillium) marneffei. PLoS ONE 2015, 10. [CrossRef]

190. Williamson, P.R. Role of laccase in the virulence of Talaromyces marneffei: A common link between AIDS-related fungal pathogens? Virulence 2016, 7, 627-629. [CrossRef]

191. Moreno, L.F.; Feng, P.; Weiss, V.A.; Vicente, V.A.; Stielow, J.B.; de Hoog, S. Phylogenomic analyses reveal the diversity of laccase-coding genes in Fonsecaea genomes. PLoS ONE 2017, 12, e0171291. [CrossRef]

192. Wei, Y.X.; Pu, J.J.; Zhang, H.; Liu, Y.N.; Zhou, F.X.; Zhang, K.L.; Liu, X.M. The laccase gene (LAC1) is essential for Colletotrichum gloeosporioides development and virulence on mango leaves and fruits. Physiol. Mol. Plant Pathol. 2017, 99, 55-64. [CrossRef]

193. Kuo, H.C.; Detry, N.; Choi, J.; Lee, Y.H. Potential roles of laccases on virulence of Heterobasidion annosum s.s. Microb. Pathog. 2015, 81, 16-21. [CrossRef]

194. Holker, U.; Dohse, J.; Hofer, M. Extracellular laccases in ascomycetes Trichoderma atroviride and Trichoderma harzianum. Folia Microbiol. 2002, 47, 423-427. [CrossRef]

195. Xu, F. Laccase. In Encyclopedia of Bioprocess Technology; Flickinger, M.C., Drew, S.W., Eds.; John Wiley \& Sons: Hoboken, NJ, USA, 1999.

196. Madhavi, V.; Lele, S.S. Laccase: Properties and applications. Bioresources 2009, 4, 1694-1717.

197. Arimoto, M.; Yamagishi, K.; Wang, J.; Tanaka, K.; Miyoshi, T.; Kamei, I.; Kondo, R.; Mori, T.; Kawagishi, H.; Hirai, H. Molecular breeding of lignin-degrading brown-rot fungus Gloeophyllum trabeum by homologous expression of laccase gene. AMB Express 2015, 5, 81. [CrossRef] [PubMed]

198. Dittmer, N.T.; Suderman, R.J.; Jiang, H.; Zhu, Y.C.; Gorman, M.J.; Kramer, K.J.; Kanost, M.R. Characterization of cDNAs encoding putative laccase-like multicopper oxidases and developmental expression in the tobacco hornworm, Manduca sexta, and the malaria mosquito, Anopheles gambiae. Insect Biochem. Mol. 2004, 34, $29-41$. [CrossRef] [PubMed]

199. Niu, B.L.; Shen, W.F.; Liu, Y.; Weng, H.B.; He, L.H.; Mu, J.J.; Wu, Z.L.; Jiang, P.; Tao, Y.Z.; Meng, Z.Q. Cloning and RNAi-mediated functional characterization of MaLac2 of the pine sawyer, Monochamus alternatus. Insect Mol. Biol. 2008, 17, 303-312. [CrossRef] [PubMed]

200. Barrett, F.M. Phenoloxidases from larval cuticle of the sheep blowfly, Lucilia cuprina - characterization, developmental-changes, and Inhibition by antiphenoloxidase antibodies. Arch. Insect Biochem. Physiol. 1987, 5, 99-118. [CrossRef]

201. Yamazaki, H.I. Cuticular phenoloxidase in Drosophila virilis. J. Insect Physiol. 1969, 15, 2203-2211. [CrossRef]

202. Li, Q.; Wang, X.; Korzhev, M.; Schroder, H.C.; Link, T.; Tahir, M.N.; Diehl-Seifert, B.; Muller, W.E. Potential biological role of laccase from the sponge Suberites domuncula as an antibacterial defense component. Biochim. Biophys. Acta 2015, 1850, 118-128. [CrossRef]

203. Tartar, A.; Wheeler, M.M.; Zhou, X.; Coy, M.R.; Boucias, D.G.; Scharf, M.E. Parallel metatranscriptome analyses of host and symbiont gene expression in the gut of the termite Reticulitermes flavipes. Biotechnol. Biofuels 2009, 2, 25. [CrossRef]

204. Hongoh, Y. Toward the functional analysis of uncultivable, symbiotic microorganisms in the termite gut. Cell Mol. Life Sci. 2011, 68, 1311-1325. [CrossRef]

205. Thomas, B.R.; Yonekura, M.; Morgan, T.D.; Czapla, T.H.; Hopkins, T.L.; Kramer, K.J. A trypsin-solubilized laccase from pharate pupal integument of the tobacco hornworm, Manduca sexta. Insect Biochem. 1989, 19, 611. [CrossRef] 
206. Dittmer, N.T.; Gorman, M.J.; Kanost, M.R. Characterization of endogenous and recombinant forms of laccase-2, a multicopper oxidase from the tobacco hornworm, Manduca sexta. Insect Biochem. Mol. Biol. 2009, 39, 596-606. [CrossRef]

207. Andersen, S.O. Insect cuticular sclerotization: A review. Insect Biochem. Mol. Biol. 2010, 40, 166-178. [CrossRef] [PubMed]

208. Andersen, S.O.; Peter, M.G.; Roepstorff, P. Cuticular sclerotization in insects. Comp. Biochem. Phys. B 1996, 113, 689-705. [CrossRef]

209. Hattori, M.; Tsuchihara, K.; Noda, H.; Konishi, H.; Tamura, Y.; Shinoda, T.; Nakamura, M.; Hasegawa, T. Molecular characterization and expression of laccase genes in the salivary glands of the green rice leafhopper, Nephotettix cincticeps (Hemiptera: Cicadellidae). Insect Biochem. Mol. Biol. 2010, 40, 331-338. [CrossRef] [PubMed]

210. De Gregorio, E.; Spellman, P.T.; Rubin, G.M.; Lemaitre, B. Genome-wide analysis of the Drosophila immune response by using oligonucleotide microarrays. Proc. Natl. Acad. Sci. USA 2001, 98, 12590-12595. [CrossRef]

211. Yatsu, J.; Asano, T. Cuticle laccase of the silkworm, Bombyx mori: Purification, gene identification and presence of its inactive precursor in the cuticle. Insect Biochem. Mol. Biol. 2009, 39, 254-262. [CrossRef]

212. Hattori, M.; Konishi, H.; Tamura, Y.; Konno, K.; Sogawa, K. Laccase-type phenoloxidase in salivary glands and watery saliva of the green rice leafhopper, Nephotettix cincticeps. J. Insect Physiol. 2005, 51, 1359-1365. [CrossRef]

(C) 2020 by the authors. Licensee MDPI, Basel, Switzerland. This article is an open access article distributed under the terms and conditions of the Creative Commons Attribution (CC BY) license (http://creativecommons.org/licenses/by/4.0/). 